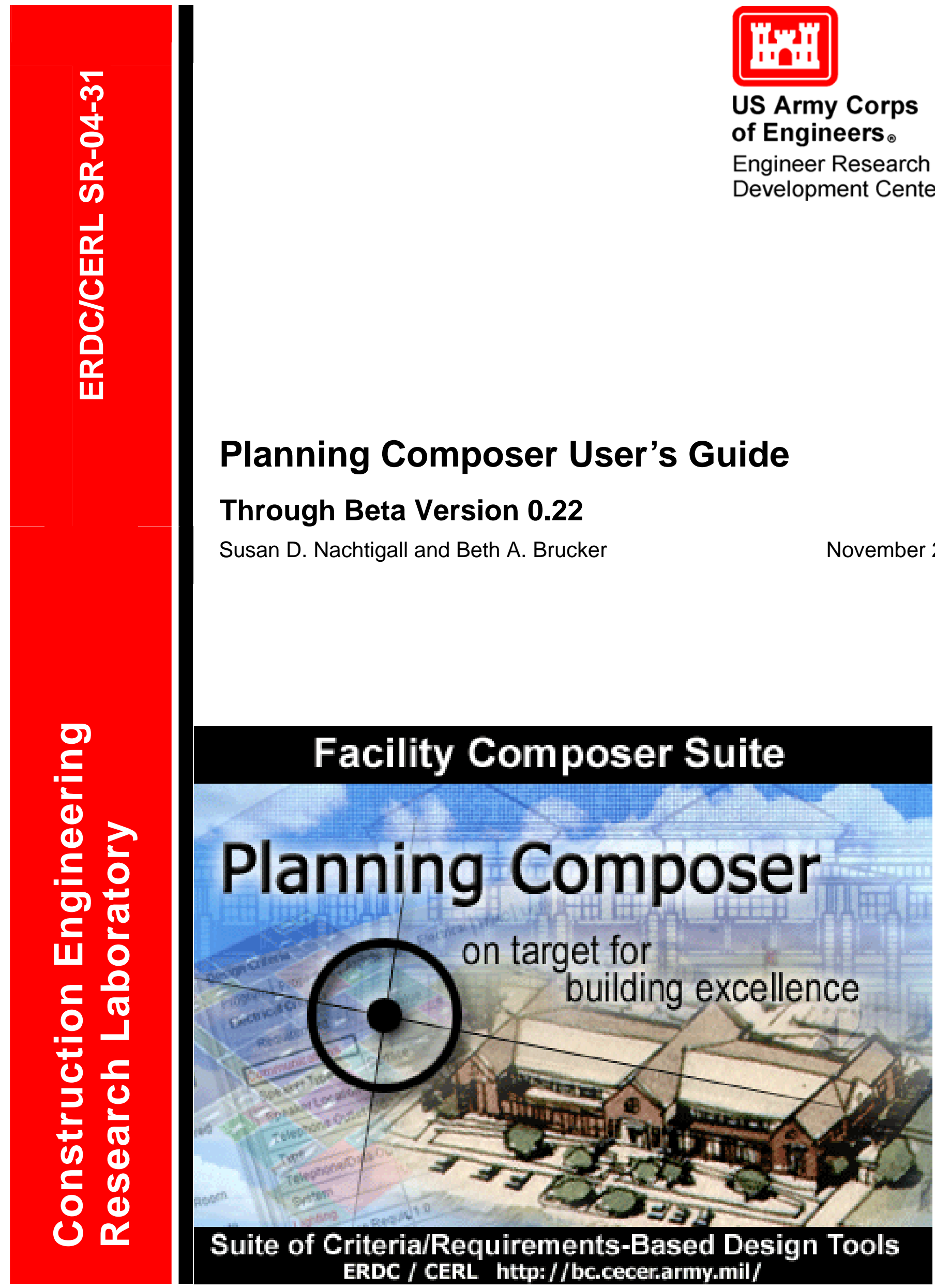




\section{Planning Composer User's Guide: Through Beta Version 0.22}

Susan D. Nachtigall and Beth A. Brucker

Construction Engineering Research Laboratory

PO Box 9005

Champaign, IL 61826-9005

Final Report

Approved for public release; distribution is unlimited.

Prepared for U.S. Army Corps of Engineers

Washington, DC 20314-1000 
ABSTRACT: Over the past several years, the Architectural Engineering and Construction (AEC) industry has been making a substantial effort to create a standard facility modeling format known as the Industry Foundation Class (IFC), which has now made it possible to capture criteria and requirements during planning and design, and then to reuse this data during the life cycle of the facility. This research effort is part of the "Fort Future" program, which is developing a capability to model, simulate, assess, and optimize installation capabilities to support the Objective Force. The Facility Acquisition component of Fort Future, Facility Composer, will shorten the time required to acquire facilities while ensuring that Objective Force and Future Combat Systems (FCS) criteria and requirements are met. Facility Composer tools support capturing and tracking of facility criteria and requirements, planning and design charrettes, and associated planning and design analyses. Planning Composer is one of the primary tools in the Facility Composer application suite, which helps users create an architectural program and to set values for project specific criteria. This work contains a User Guide for the Planning Composer software.

DISCLAIMER: The contents of this report are not to be used for advertising, publication, or promotional purposes.

Citation of trade names does not constitute an official endorsement or approval of the use of such commercial products.

All product names and trademarks cited are the property of their respective owners. The findings of this report are not to be construed as an official Department of the Army position unless so designated by other authorized documents.

DESTROY THIS REPORT WHEN IT IS NO LONGER NEEDED. DO NOT RETURN IT TO THE ORIGINATOR. 


\section{Contents}

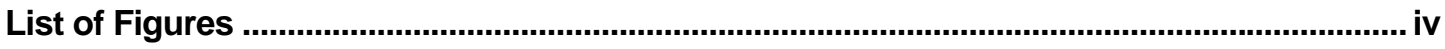

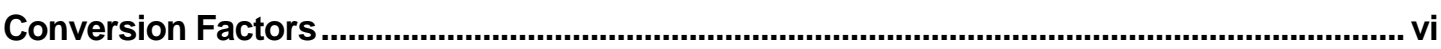

Preface

1 Introduction

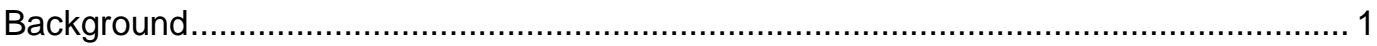

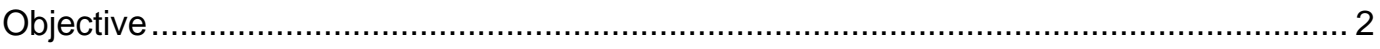

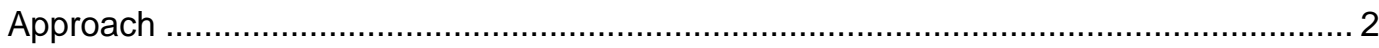

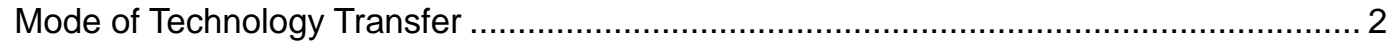

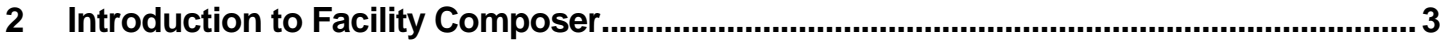

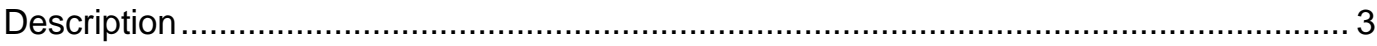

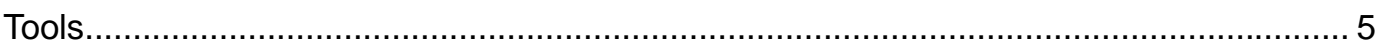

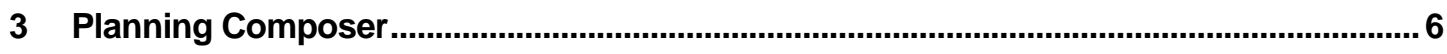

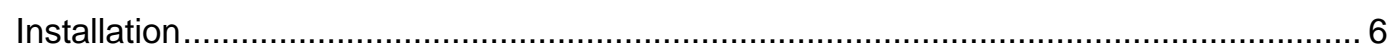

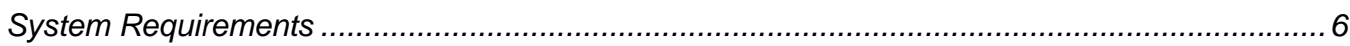

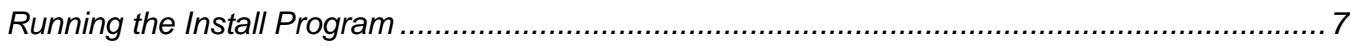

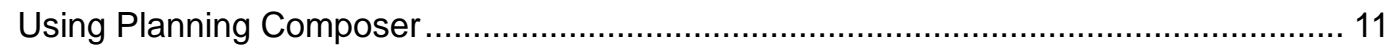

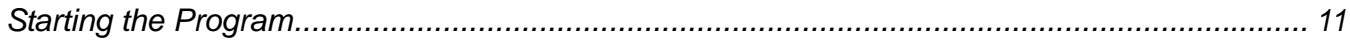

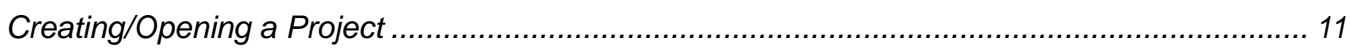

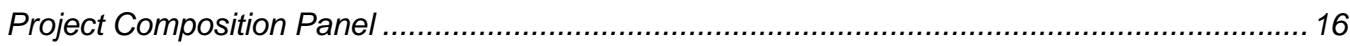

Working with Function Templates ................................................................................ 18

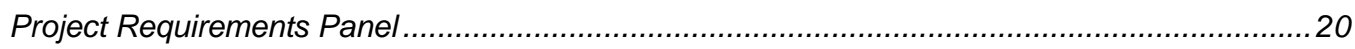

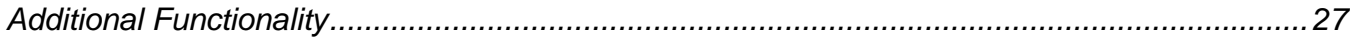

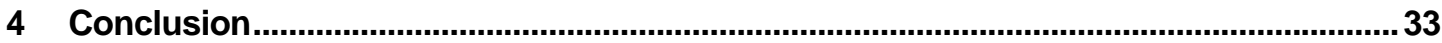

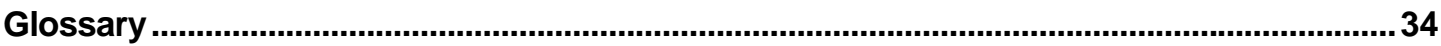

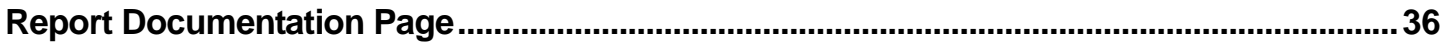




\section{List of Figures}

\section{Figures}

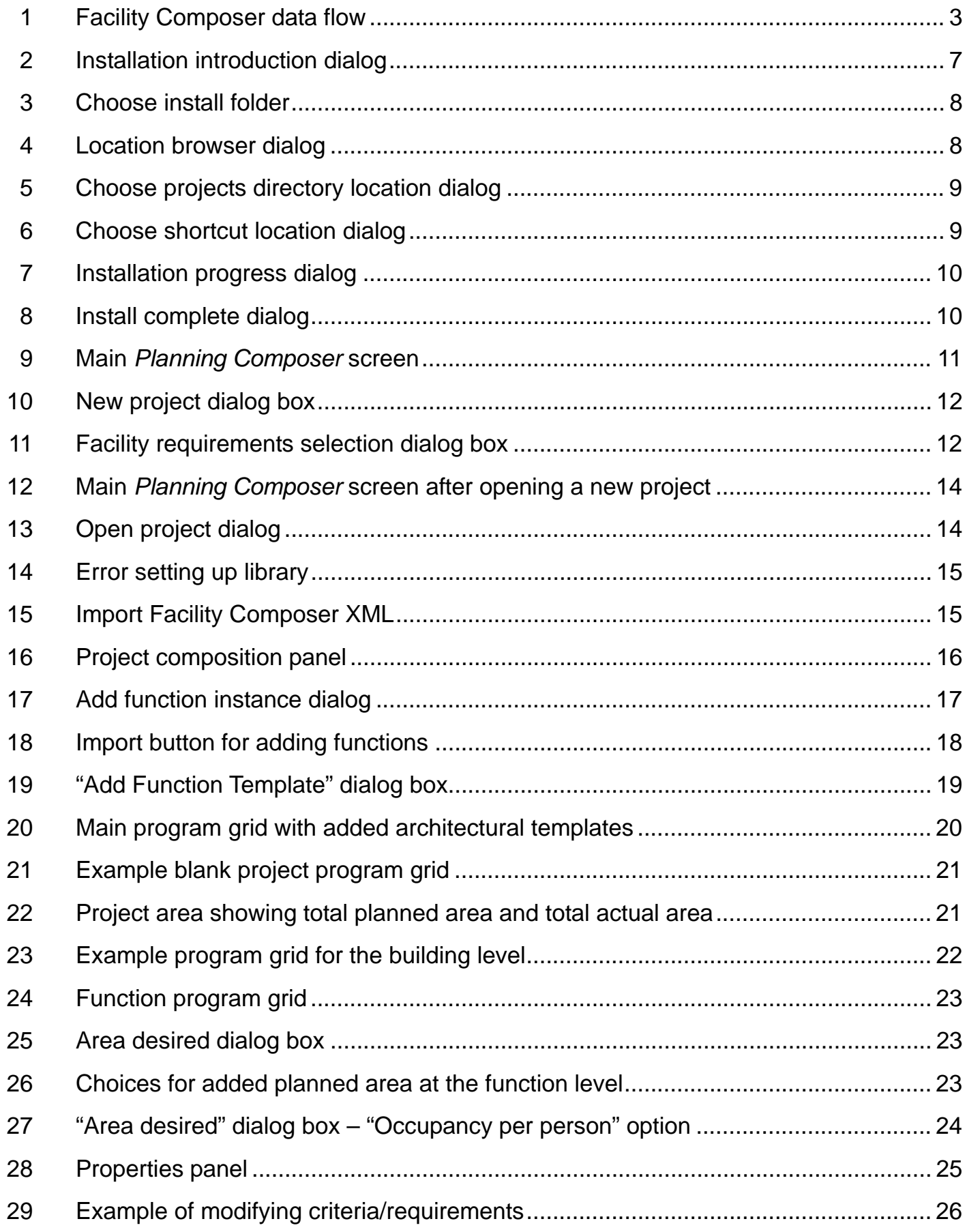




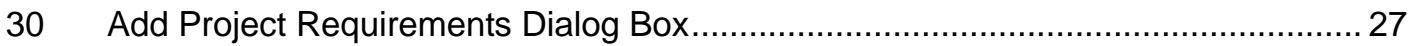

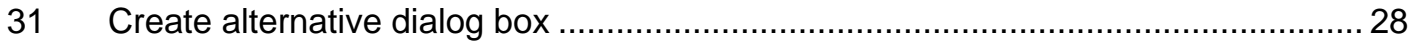

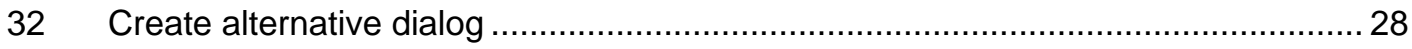

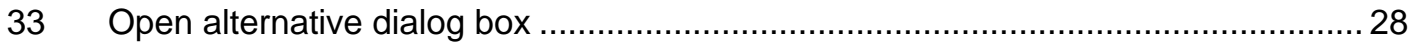

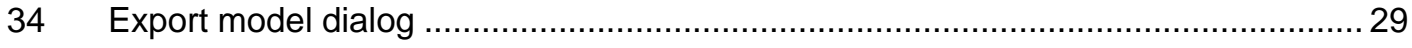

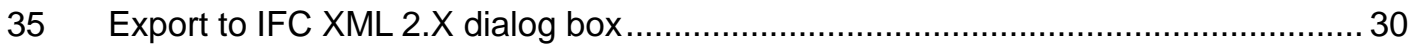

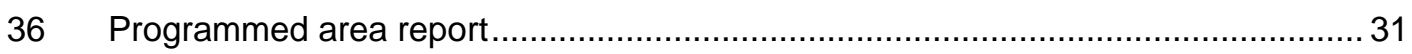

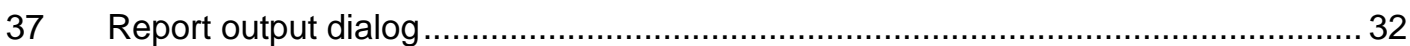




\section{Conversion Factors}

Non-SI ${ }^{*}$ units of measurement used in this report can be converted to SI units as follows:

\begin{tabular}{|c|c|c|}
\hline Multiply & By & To Obtain \\
\hline acres & $4,046.873$ & square meters \\
\hline cubic feet & 0.02831685 & cubic meters \\
\hline cubic inches & 0.00001638706 & cubic meters \\
\hline degrees (angle) & 0.01745329 & radians \\
\hline degrees Fahrenheit & $(5 / 9) \times\left({ }^{\circ} \mathrm{F}-32\right)$ & degrees Celsius \\
\hline degrees Fahrenheit & $(5 / 9) \times\left({ }^{\circ} \mathrm{F}-32\right)+273.15$ & kelvins \\
\hline feet & 0.3048 & meters \\
\hline gallons (U.S. liquid) & 0.003785412 & cubic meters \\
\hline horsepower (550 ft-lb force per second) & 745.6999 & watts \\
\hline inches & 0.0254 & meters \\
\hline kips per square foot & 47.88026 & kilopascals \\
\hline kips per square inch & 6.894757 & megapascals \\
\hline miles (U.S. statute) & 1.609347 & kilometers \\
\hline pounds (force) & 4.448222 & newtons \\
\hline pounds (force) per square inch & 0.006894757 & megapascals \\
\hline pounds (mass) & 0.4535924 & kilograms \\
\hline square feet & 0.09290304 & square meters \\
\hline square miles & $2,589,998$ & square meters \\
\hline tons (force) & $8,896.443$ & newtons \\
\hline tons ( 2,000 pounds, mass) & 907.1847 & kilograms \\
\hline yards & 0.9144 & meters \\
\hline
\end{tabular}

\footnotetext{
*Système International d'Unités ("International System of Measurement"), commonly known as the "metric system."
} 


\section{Preface}

This study was conducted for Headquarters, U.S. Army Corps of Engineers (HQUSACE) under Project "Fort Future"; Work Unit LK6K75-N, "Fort Future Facilities." The technical monitors were Paul A. Howdyshell, CEERD-CF-M and Michael P. Case, CEERD-CF-N, Special Projects Officer for Fort Future.

The work was performed by the Engineering Processes Branch (CF-N) of the Facilities Division (CF), Construction Engineering Research Laboratory (CERL). The CERL Project Manager was Beth A. Brucker. Recognition is due to Jeff Heckel, Wayne Smith, Russ Northrup, William Zwicky and Van Woods for their contribution to the development of the Facility Composer Suite of Tools. Also special recognition is due to Matthew R. Geaman and Ronnie B. Pride, Research Assistants from the University of Illinois, for contribution to this document. The technical editor was William J. Wolfe, Information Technology Laboratory. Donald K. Hicks is Chief, CEERD-CF-N, and L. Michael Golish is Chief, CEERD-CF. The associated Technical Director was Paul A. Howdyshell, CEERD-CF-M. The Director of CERL is Dr. Alan W. Moore.

CERL is an element of the U.S. Army Engineer Research and Development Center (ERDC), U.S. Army Corps of Engineers. The Commander and Executive Director of ERDC is COL James R. Rowan, and the Director of ERDC is Dr. James R. Houston. 


\section{Introduction}

\section{Background}

The Architectural Engineering and Construction (AEC) industry has been making a substantial effort over the past several years to create a standard facility modeling format that better enables their different software applications to work together. This emerging standard, known as the Industry Foundation Class (IFC), is being developed by the International Alliance for Interoperability (IAI) and can be found in recent releases of commercial AEC software.

The evolution of this facility modeling standard, has now made it possible to capture criteria and requirements during planning and design, and then to reuse this data during the life cycle of the facility. Providing interoperability among planning, design, construction, operations and maintenance, and recycling software applications will reduce the time necessary to process information about the facilities.

This research effort is part of the "Fort Future" program being conducted by the U.S. Army Engineer Research and Development Center (ERDC) in support of the Office of the Assistant Chief of Staff for Installation Management (OASCIM) and the Installation Management Agency (IMA). The key objective of Fort Future is to develop a capability to model, simulate, assess, and optimize installation capabilities to support the Objective Force. Fort Future users at the installation, regional, or national level will be able to set up planning scenarios, conduct dynamic analysis over a period of up to 30 years, and compare scenario results using a virtual installation.

Before Objective Force brigades can be deployed, installations must conduct analyses to determine their facility requirements. The difficulty of this task is compounded by the fluid state of information about the Future Combat System (FCS) and the long lead time (5 to 7 years for large facilities) built into the Military Construction, Army (MCA) and National Environmental Policy Act (NEPA) processes. Installations designated for Stryker Brigade Combat Teams (SBCTs) have been overloaded with requirements to produce large numbers of planning documents in a very short time. Under the Unit Set Fielding process, future 
combat systems cannot be fielded until supporting facilities are in place. This requirement that puts yet more pressure on the MCA process.

The Facility Acquisition component of Fort Future, Facility Composer, will shorten the time required to acquire facilities while ensuring that Objective Force and FCS criteria and requirements are met. Facility Composer tools support capturing and tracking of facility criteria and requirements, planning and design charrettes, and associated planning and design analyses. Planning Composer is one of the primary tools in the Facility Composer application suite, which helps users create an architectural program and to set values for project specific criteria.

\section{Objective}

The overall objective of this work is to design and produce a suite of tools for use by facility planners, designers, and engineers during the initial phases of facility planning and design. The specific objective of this part of the project is to devise and publish a User Guide for the Planning Composer software.

\section{Approach}

This document is meant to serve as an overall user guide to accompany the Planning Composer software. It includes:

1. A general description if the program and its tools (p 3)

2. System requirements and installation instructions (p 6)

3. Step-by-step program instructions for principal program functions (pp 11-32)

4. A glossary of technical terminology ( $p$ 34)

\section{Mode of Technology Transfer}

This report will be made accessible through the World Wide Web (WWW), as a laboratory publication through the CERL website, at URL:

http://www.cecer.army.mil

and directly to users through the Facility Composer website, at URL:

https://ff.cecer.army.mil/fc 


\section{Introduction to Facility Composer}

\section{Description}

Facility Composer is a suite of tools for use by facility planners, designers, and engineers during the initial phases of facility planning and design. While originally developed to support the design of government facilities, Facility Composer is based on the general concepts of: (1) providing a method to effectively and creatively create and use criteria libraries, (2) providing support for architectural programming and project specific criteria specification during interactive design charrettes or at the designer's desktop, and (3) supporting the creative and analytical aspects of architectural conceptual design involving the creation of one or many solutions from the specified criteria in an intuitive design environment. While not enforcing any particular design process, Facility Composer is designed to be able to support the process flow shown in Figure 1.

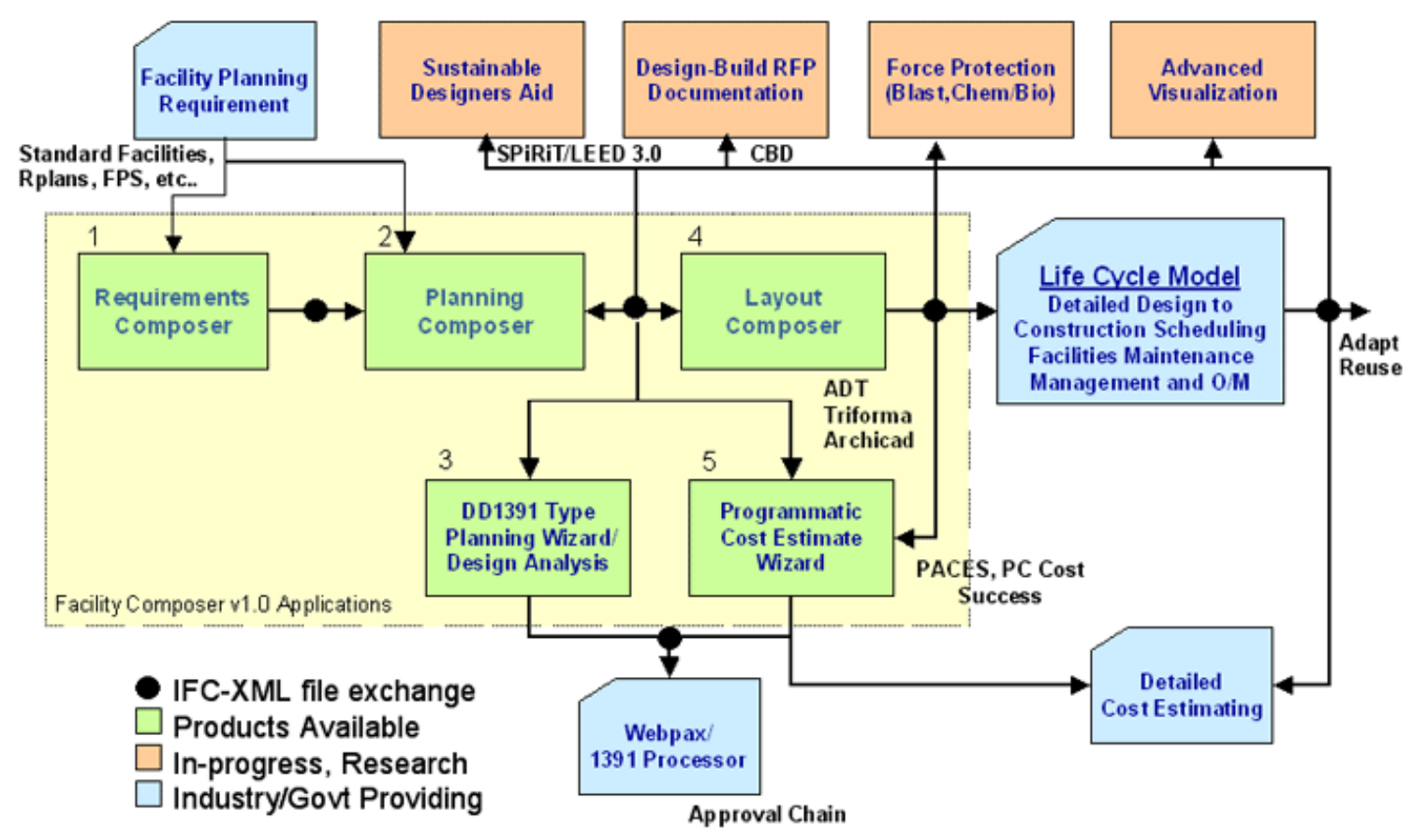

Figure 1. Facility Composer data flow. 
The most important concept of Facility Composer is that customer-specific and computable criteria are associated with a growing facility model that continues throughout the life cycle of the facility. While many volumes of government design criteria exist in the form of design guides, regulations, technical manuals, and web pages, few, if any, of these are expressed in a computable format. In addition, current design systems do not provide a way to directly interact with these criteria, nor do they provide an efficient way to extend the functionality of an application to directly support criteria usage. With the evolution of facility modeling standards, these restrictions will be overcome by emerging design systems.

In Facility Composer, criteria can be associated with different project elements based on the appropriate level of detail, from the project to the site, the building, story, function, and down to the individual space. For example, Facility Composer allows one to specify that a target schedule and cost be associated with a project, that masonry exterior walls and a steel structure be used on a building, that 32-Watt T-8 florescent lights be used in corridors and 50 foot-candles be maintained in the offices, and that a particular room will have VCT flooring. Facility Composer's ability to maintain a linkage between criteria and project elements (site, building, story, etc.) provides many benefits:

- It helps ensure that critical criteria are followed, and that desired characteristics are recorded and addressed.

- It helps organize criteria and makes it available at its point of use. It helps in defining criteria and can help in recording its rationale.

- It simplifies creation, maintenance, and distribution of new criteria. For example, as requirements that better implement sustainable design principles are developed, these are added to an organization's standard library for use in subsequent projects. These libraries are typically organized around facility type, but are not required to be.

It helps support rapid conceptual and detailed design and analysis (cost, structural, HVAC, energy, electrical, O\&M, etc.) either directly or through standards, such as the International Alliance for Interoperability's Industry Foundation Classes (IAI-IFC) and Building Lifecycle Interoperable Software (BLIS).

Owners with numerous facility holdings, in particular, reap benefits from this approach as it helps ensure the initial design satisfies their corporate criteria, shortening the review process and avoiding "design by review." All of these benefits result in cost and time savings by reducing user changes late in the design process or during construction. Design quality is also enhanced, as many alternatives can be explored rapidly. 


\section{Tools}

The primary tools in the Facility Composer application suite include:

- Requirements Composer, a web-based application that helps in the development of corporate and building specific criteria libraries

- Planning Composer, which helps users create an architectural program and to set values for project specific criteria

- Layout Composer, provides an environment for the designer/user to rapidly create $2 \mathrm{D}$ and $3 \mathrm{D}$ conceptual facility designs solutions

- Wizards that provide support for various discipline specific issues and assist in the completion of individual design tasks and calculations. 


\section{Planning Composer}

Planning Composer is used to develop a facility "architectural" program and to add and set project specific criteria. This includes traditional information such as the total project area and allocation of area to specific architectural functions such as circulation and offices. It also contains discipline-specific criteria such as requirements for structural, electrical, HVAC, lighting, and plumbing. The level of detail in the architectural program varies from project to project, and can be specified as such in the system.

With just a few parameters set, the information in Planning Composer is sufficient to prepare a preliminary cost estimate and schedule. For example, it is acceptable to create a project that contains a list of architectural functions and their allocated areas without deciding how many buildings will be required. On the other hand, the planner may create a project with detailed information such as the number of buildings and the number of stories in each building. Obviously, the latter cost estimate will be more accurate. Typically, the planner will not create such a detailed program from scratch, but will copy it from a similar project and tailor it to suit the current customer's needs. Users benefit from Planning Composer not only because it provides a method to capture, use, and reuse this explicit criteria, but also because it can often assist designers by providing a deeper understanding of the rationale behind certain decisions, from which other, better, solutions could be considered.

This guide will explain currently functionality within the system. For Documentation and specific examples on how to use the software for developing a project, please see ERDC/CERL SR-04-30, Planning Composer: Tutorial (Construction Engineering Research Laboratory [CERL], November 2004).

\section{Installation}

\section{System Requirements}

- Planning Composer requires approximately $35 \mathrm{MB}$ of hard disk space.

- Your computer must be capable of running Java Virtual Machine 1.22.

- Microsoft Access database drivers must be installed on your computer. 


\section{Running the Install Program}

Planning Composer is delivered on CD or via the Web at the Facility Composer Website (http://ff.cecer.army.mil/fc/download.jsp). You may choose to install the program directly from either source, or you can first save the compressed installation file on your hard drive.

If you choose to install directly, the install file will automatically decompress and start the install process. If you have saved the install file to your hard drive, double click on it to start the install. In either case, the Installation Introduction dialog (Figure 2) will appear.

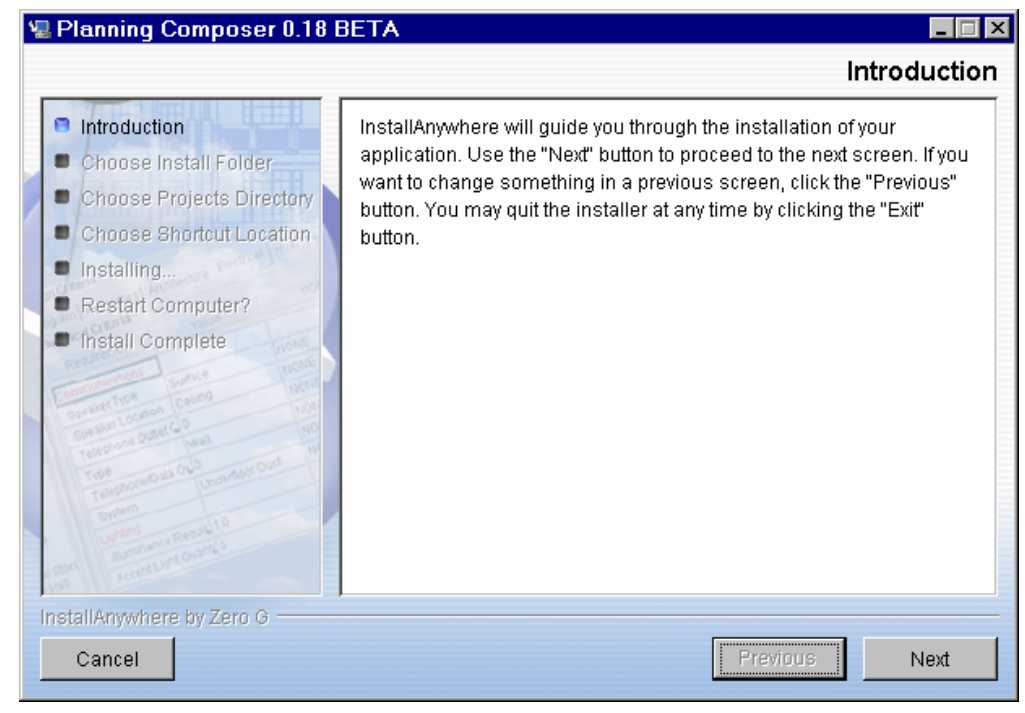

Figure 2. Installation introduction dialog.

The installer will lead you through the process as follows.

Click the [Next] button. (As you proceed, you may use the Previous button to go back and change settings made earlier in the process.) The Choose Install Folder dialog (Figure 3) should now appear. 


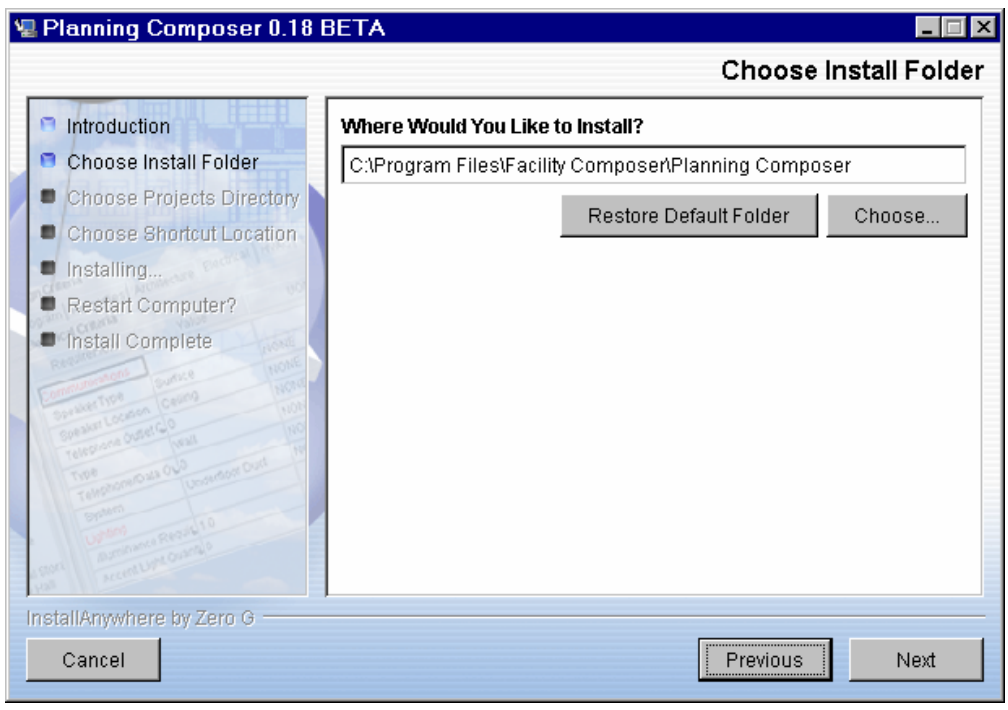

Figure 3. Choose install folder.

The default installation location is displayed in the edit box. To select a location other than the default, you can type it in the edit box or click the [Choose...] button. A file browser dialog (Figure 4) will appear, allowing you to select a different location. To go back to the default location originally listed in the Choose Install Folder dialog, click the [Restore Default Location] button.

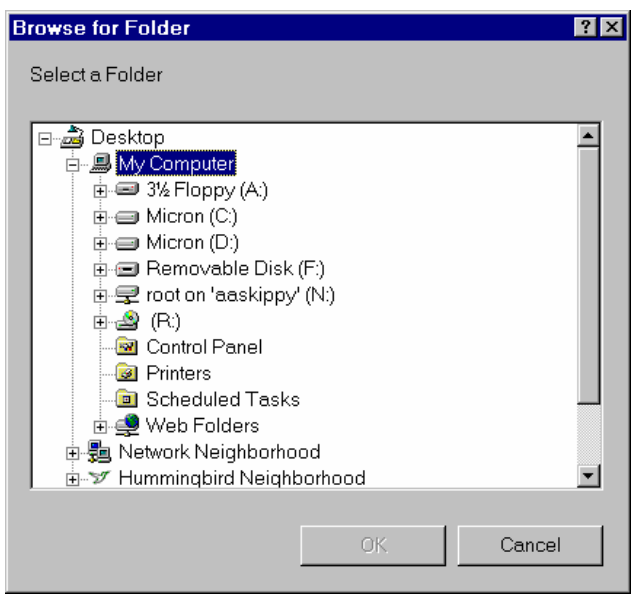

Figure 4. Location browser dialog.

Once you have selected a location, click the [Next] button. The Choose Projects Directory dialog box should appear. The default installation location is displayed in the edit box. To select a location other than the default, you can type it in the edit box or click the [Choose...] button. A file browser dialog (Figure 5) will appear, allowing you to select a different location. To go back to the default location originally listed in the Choose Install Folder dialog, click the [Restore Default Location] button. 


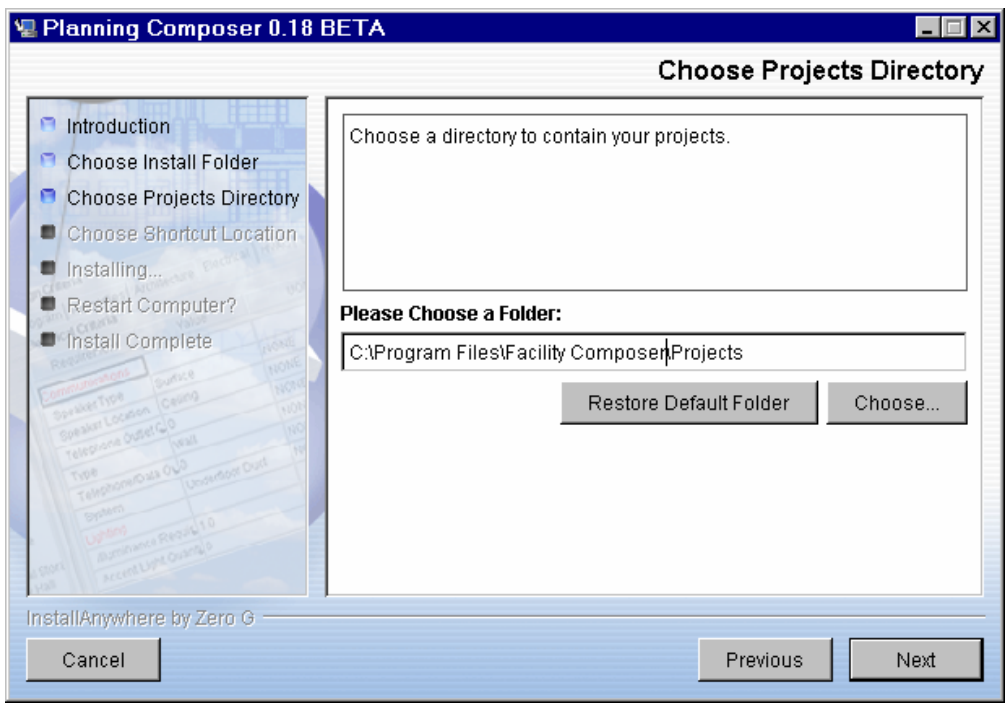

Figure 5. Choose projects directory location dialog.

Once you have selected a location, click the [Next] button. The Choose Shortcut Location dialog box (Figure 6) should appear.

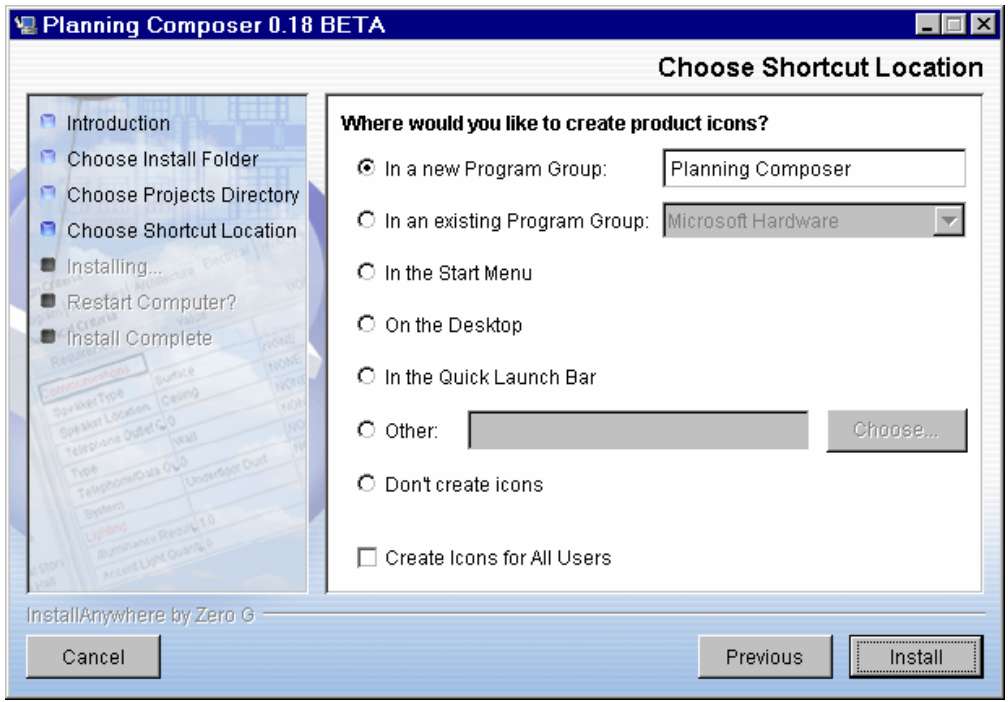

Figure 6. Choose shortcut location dialog.

Use the radio buttons to designate where application icons or shortcuts should go. If you create a new program group, its default name will be Planning Composer, but you can type in a new name in the edit box. If you select an existing program group, use the dropdown menu to the right of the radio button to select the desired group. If you select Other, use the adjacent edit box to enter a path and location, or click the [Choose...] button to display a browser dialog that will allow you to select a different location. When finished, click [Install]. A progress 
dialog containing the Facility Composer splash screen (Figure 7) will appear during the installation process, which will take a few moments.

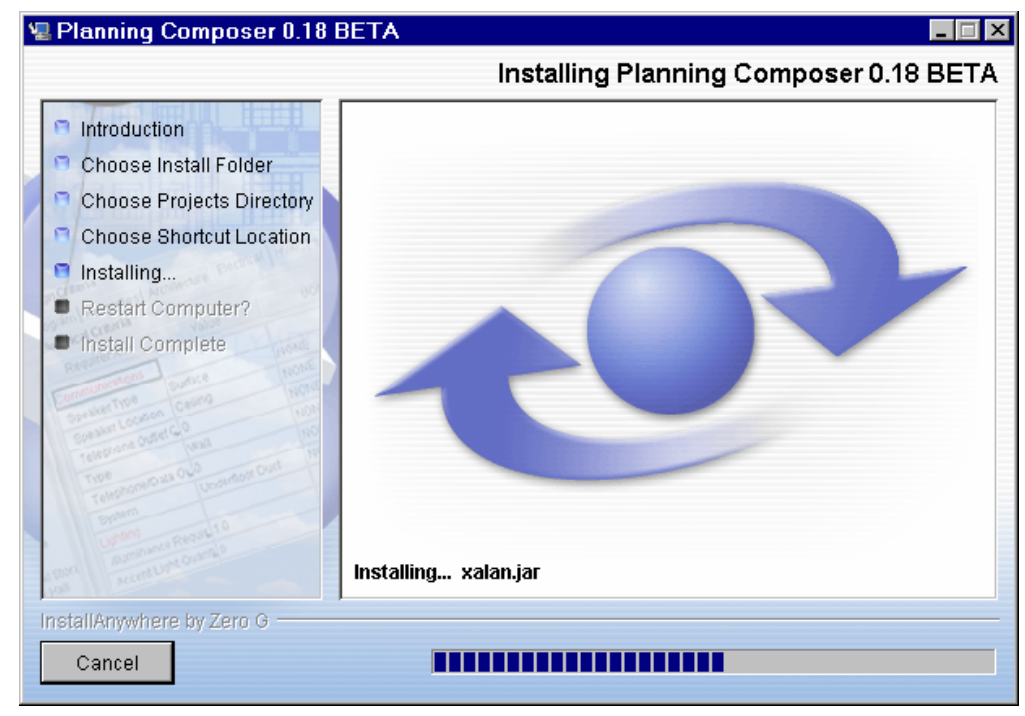

Figure 7. Installation progress dialog.

When installation is complete, the Install Complete dialog (Figure 8) will appear.

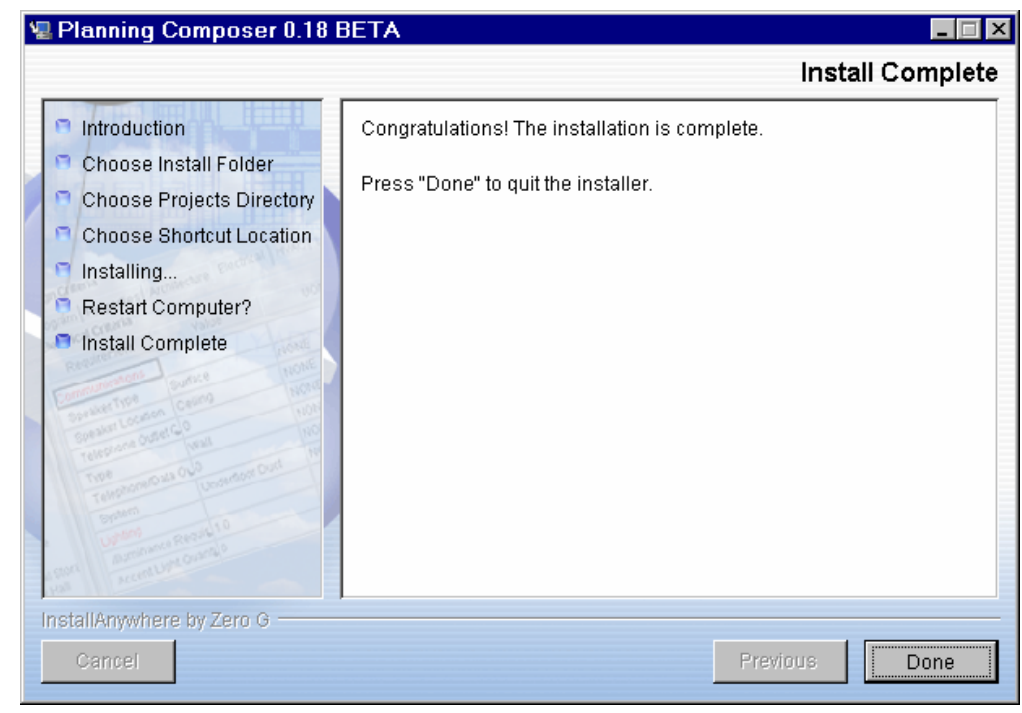

Figure 8. Install complete dialog.

When the Install Complete dialog appears, click [Done] to complete the installation. One more dialog will appear briefly with the message "Install Anywhere Is Cleaning Up." 


\section{Using Planning Composer}

\section{Starting the Program}

Start Planning Composer by clicking on the desktop startup icon:

Result: The Main Planning Composer screen (Figure 9) appears.

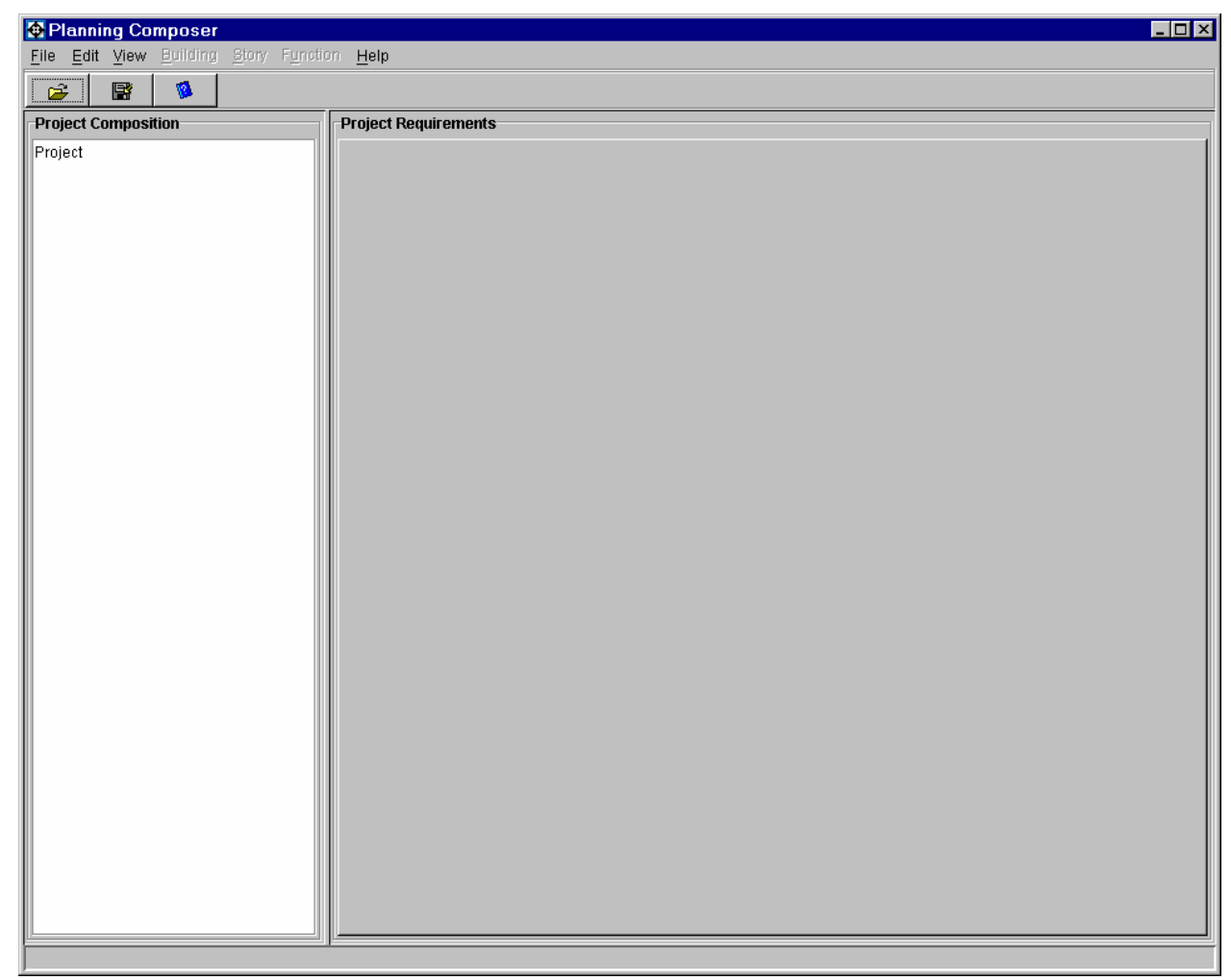

Figure 9. Main Planning Composer screen.

\section{Creating/Opening a Project}

\section{Creating a New Project}

From the File menu, choose New, and then Project...

Result: The New Project dialog box (Figure 10) opens. 


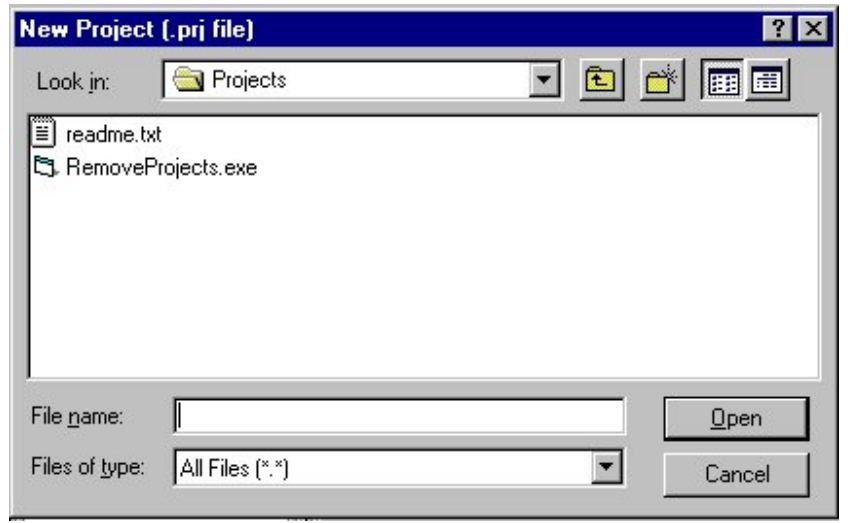

Figure 10. New project dialog box.

Enter a meaningful file name for your new project and click the $\square$ pen button. (The name that you choose will be assigned to the project file. In addition, a directory will be created using this name to hold the project data.)

\section{Setting the Default Library}

The new project may take a moment or two to load. Then the Facility Requirements Selection dialog box (Figure 11) will appear.

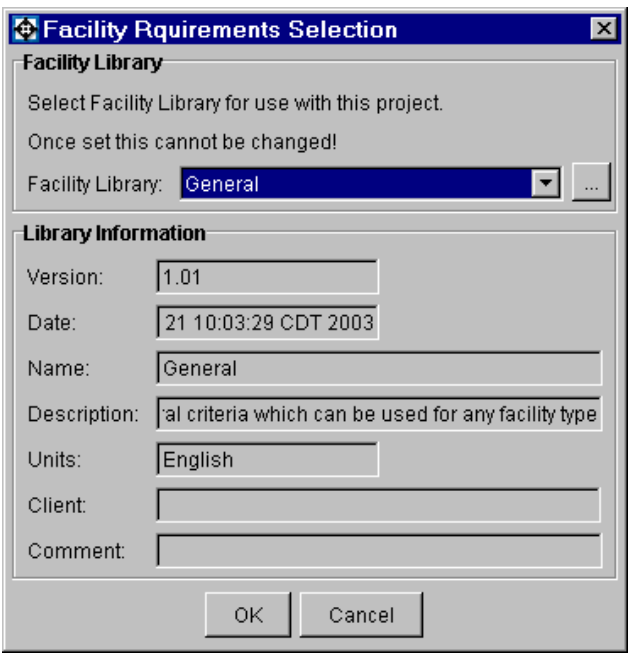

Figure 11. Facility requirements selection dialog box.

Here you will select the Facility Library for use with this project. At your site, you may have access to a number of libraries containing object criteria and function templates. The pull-down menu will display your options. If you have saved libraries, that do not appear in the pull down bar, click the $\ldots .$. button next to the pull down bar to manually browse for your library. Once you have chosen a default or baseline facility library and committed by clicking the [OK] button, this 
library is permanently linked to your project and may not be changed at a later time, although additional libraries may be added over the course of the project through the addition of Components If you need to access a different base library at some future date, you will need to create a new project.

The bottom portion of the Facility Requirements Selection dialog box displays the Library Information. Select a library in the top portion of the screen and view the information about this library here. Make special note of the Units field. This field specifies the unit of measure that is used for the criteria/requirements in this library. If the unit is set to Metric, then all linear measurements will be in millimeters and all area measurements will be in square meters; if the unit is English, then all linear measurements will be in feet and all area measurements will be in square feet. This is an important consideration and may not be changed later, so choose a library whose units are appropriate for your project.

Click the $\mathrm{OK}$ button to complete the selection.

As stated previously, once the Facility Library has been set for the project, it cannot be changed.

Result: The main screen (Figure 12) opens again. This time the Project and Site are displayed in the Project Composition panel. The name of the open project file appears across the top of the window, along with the base Unit and the Alternative name. (Alternatives will be discussed later in the manual.) 


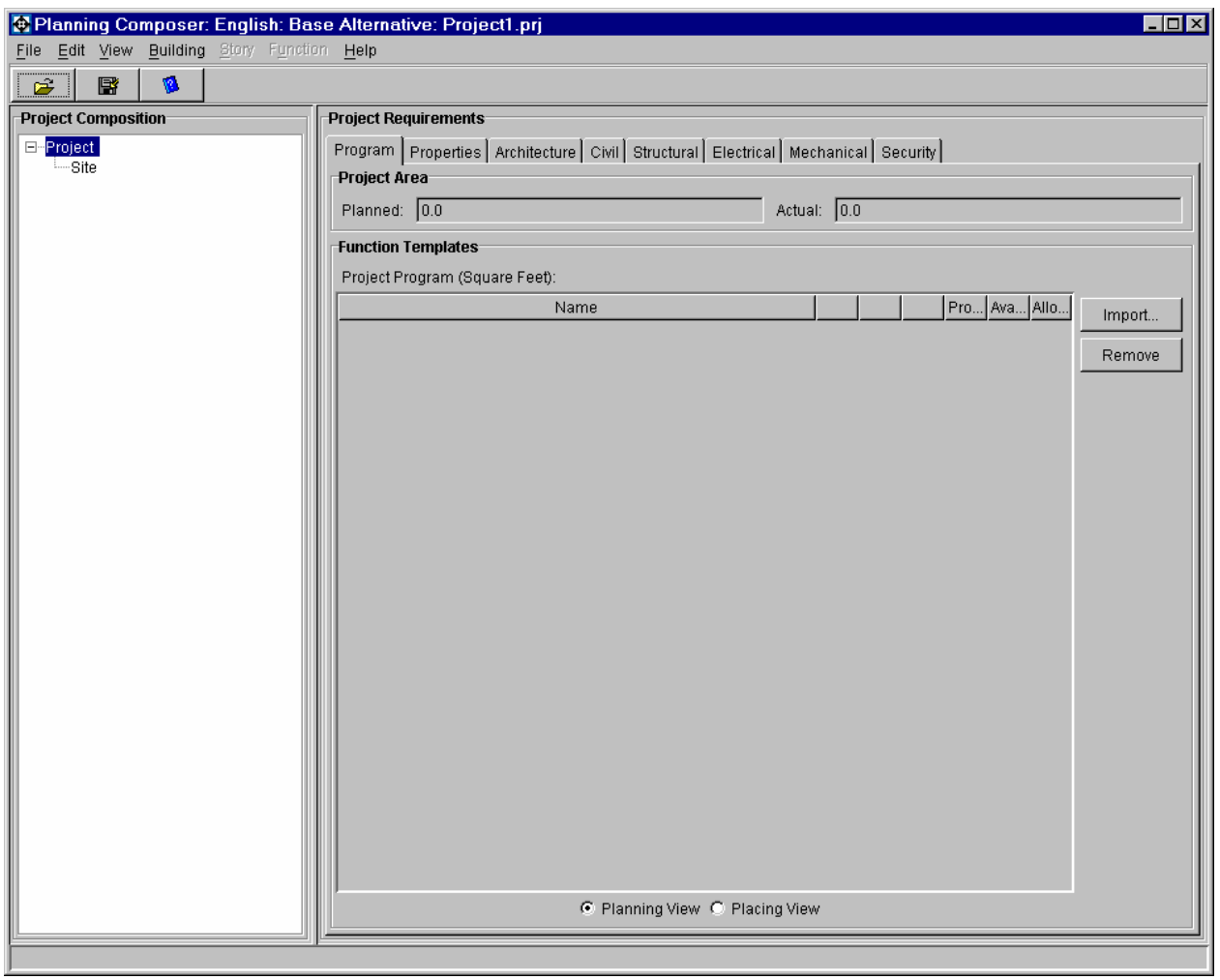

Figure 12. Main Planning Composer screen after opening a new project.

\section{Opening an Existing Project}

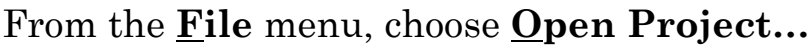

Result: The Open Project dialog box (Figure 13) opens.

\begin{tabular}{|c|c|c|c|}
\hline Open Project (.prj file) & & & $? \times$ \\
\hline Look in: G Projects & $\nabla$ & $\leftarrow €$ & 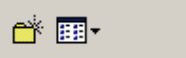 \\
\hline $\begin{array}{l}7 \text { battalion ha } \\
\text { company ops-large } \\
\text { company ops-medium } \\
\text { company ops-small } \\
\text { dining facility 501-800 } \\
\text { example }\end{array}$ & $\begin{array}{l}\text { Dexample program } \\
\text { Gifcxml } \\
\text { khikihui } \\
\text { nash } \\
\text { nash2 } \\
\text { nash3 }\end{array}$ & & $\begin{array}{l}\text { nashville } \\
9 \text { nashville } 5 \\
9 \text { nashville traini } \\
9 \text { nashville traini } \\
9 \text { paces } \\
\square \text { paces progran }\end{array}$ \\
\hline 1 & & & $\perp$ \\
\hline File name: & & & Qpen \\
\hline Files of type: All Files $\left[{ }^{\times} .{ }^{x}\right]$ & & $\nabla$ & Cancel \\
\hline
\end{tabular}

Figure 13. Open project dialog.

Select the project you wish to open and click the $\underline{0}$ ben button. The file will have the extension *.prj. The corresponding project will then load into the Main Planning Composer Screen. 
Note: Should you receive the following error (Figure 14) indicating that a new library needs to be selected simply click the [OK] button and select a new library for the project. Refer to the section "Setting the Default library" for more information.

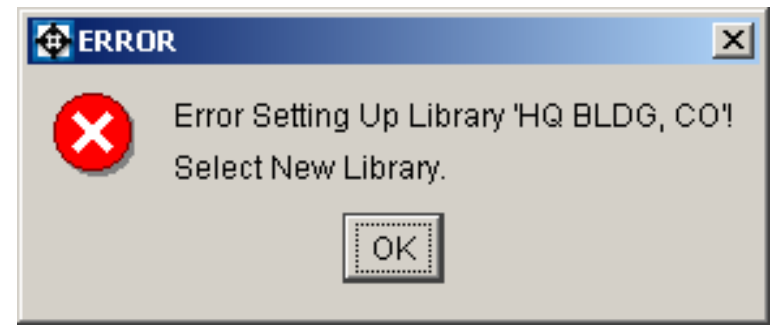

Figure 14. Error setting up library.

\section{Importing a Project}

This file format is used specifically for the Facility Composer Suite of tools. Should you receive a new version of the software, you may be required to open your old projects using this method instead of selecting the ${ }^{*}$.prj file.

From the File menu, choose Import, and then Import Model from Facility Composer XML...

Result: Import Facility Composer XML Model Dialog (Figure 15) opens

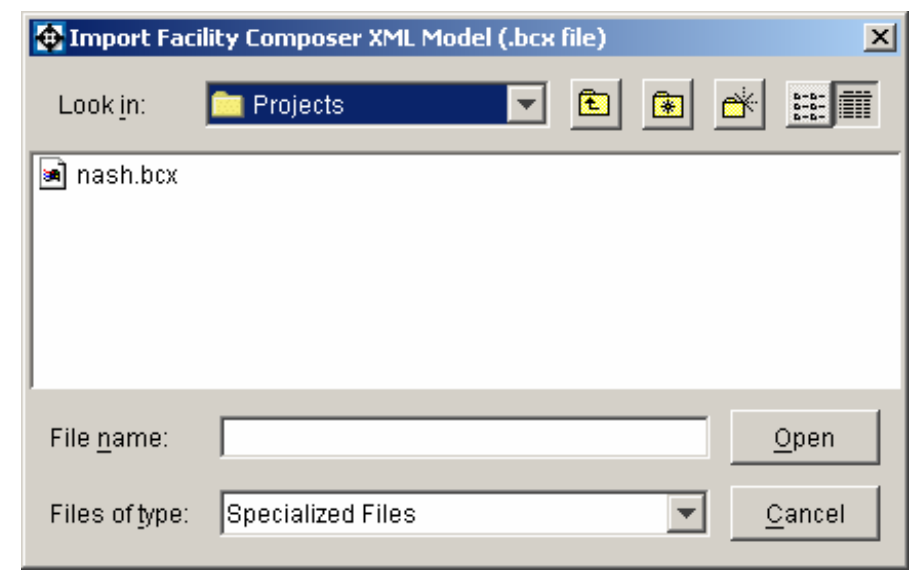

Figure 15. Import Facility Composer XML.

Using the dialog, browse to find the project you wish to import. This file will have the extension *.bcx and will be located in the $1 \backslash$ Projects $\backslash<$ project name $>\backslash$ base directory. Click the $\underline{Q}$ pen button to continue. 
Next you will be prompted to enter a new project name. This is the same process as creating a new blank project.

\section{Project Composition Panel}

\section{Composition Tree}

The Project Composition Panel (Figure 16) is where the hierarchy of the project is displayed. When a new project is started, the Project level and Site level are the only items which are displayed in this panel. As you develop and refine your project, more elements i.e., Buildings, Stories, and Function Instances will be displayed in this area.

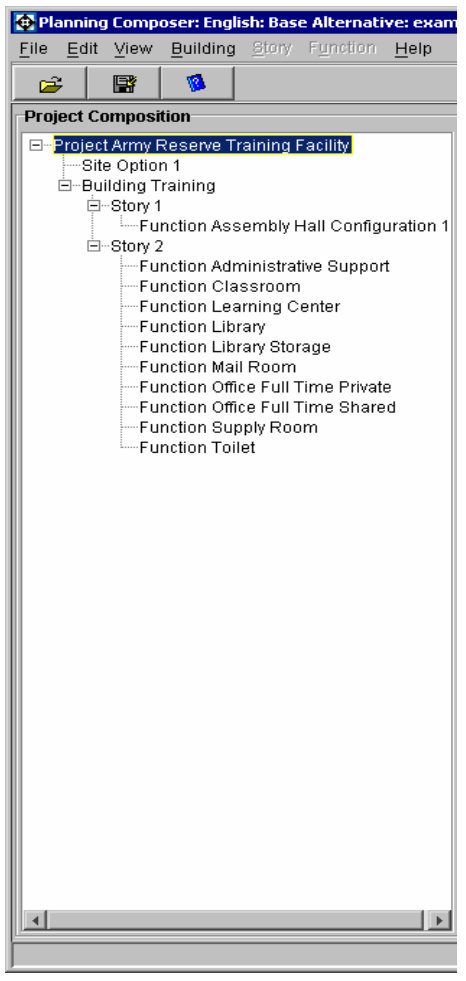

Figure 16. Project composition panel.

\section{Adding and Removing Buildings}

Highlight the Project Level in the Project Composition Panel. From the

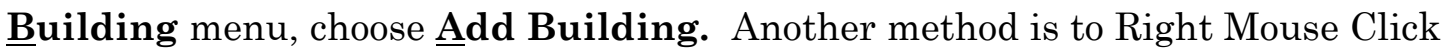

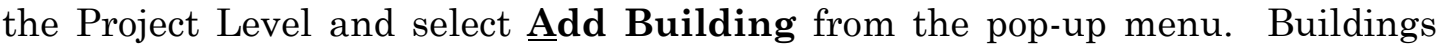
can only be added to Projects. There is no limit on the number of Buildings that can be added to a Project. 
To remove a Building from the project, simply select the Building in the tree and

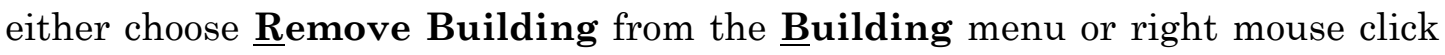

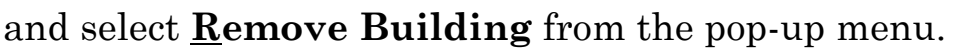

\section{Adding and Removing Stories}

To add a Story, highlight the Building object in the Project Composition Panel.

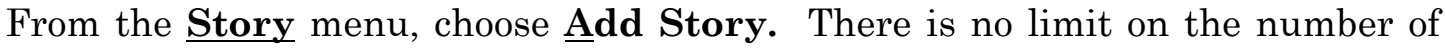
Stories, but Story Objects can only be added to Buildings.

Removing a Story is similar to removing a Building.

\section{Adding and Removing Function Instances}

To add a Function Instance, highlight the Site or Story which you wish to add

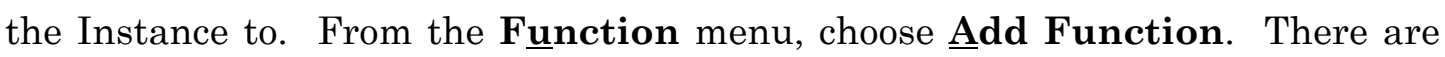
no limits on the number for Function Instances that can be added to the Site Object or Story Objects.

Result: The Add Function Instance Dialog appears (Figure 17).

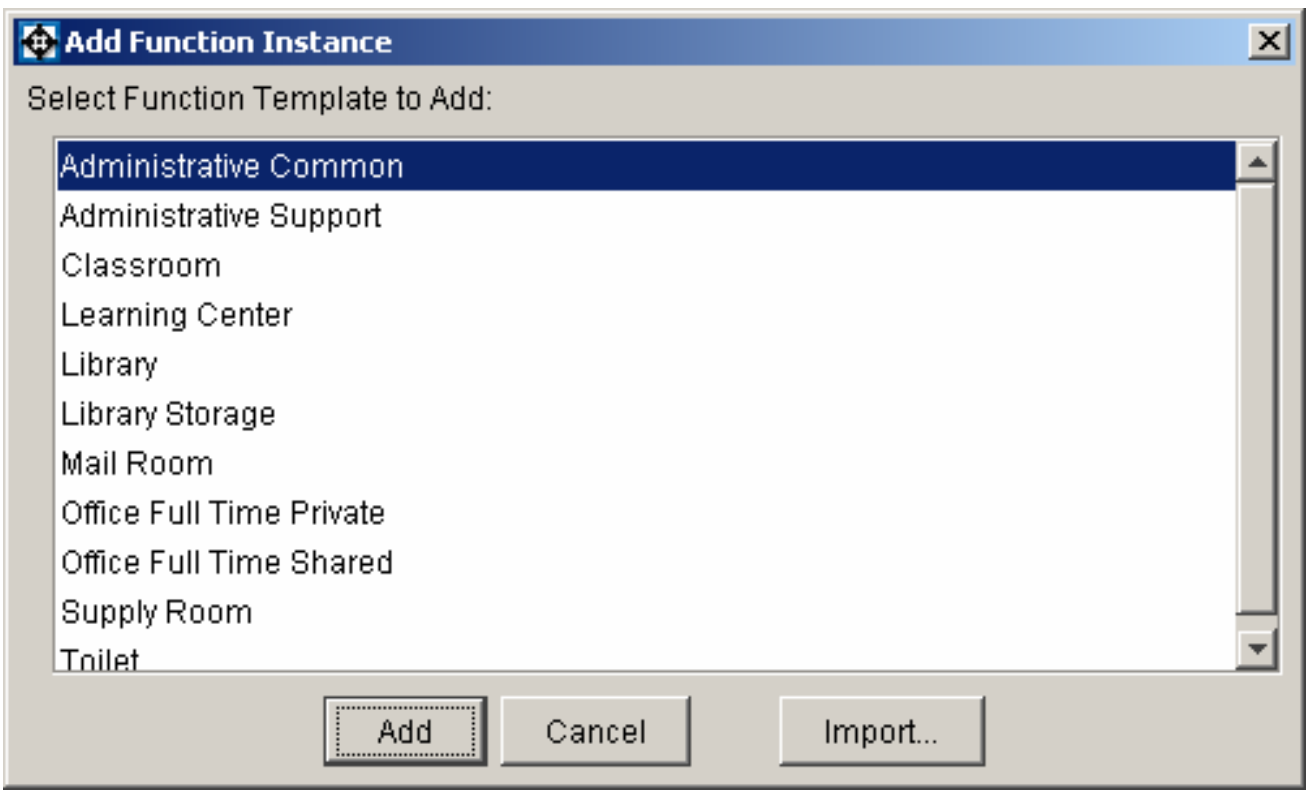

Figure 17. Add function instance dialog.

If Function Templates have already been associated with the project (See "Working with Function Templates"), they will be displayed in the dialog box. Simply highlight the Function Template you wish to add to the project and click on the [Add] button. You may select more than one Function Template at a time by 
using either the $<$ Shift $>$ or $<$ CTRL $>$ keys. If the template you wish to add is not in the list, click the Import.. button and the bottom right of the Function Instance dialog box (Figure 17), then follow the procedures listed in the following section to add new templates.

Removing a Function Instance is similar to removing a Building or Story.

\section{Working with Function Templates}

Importing a Function Template

Click the Import... button next to the Function Templates grid.

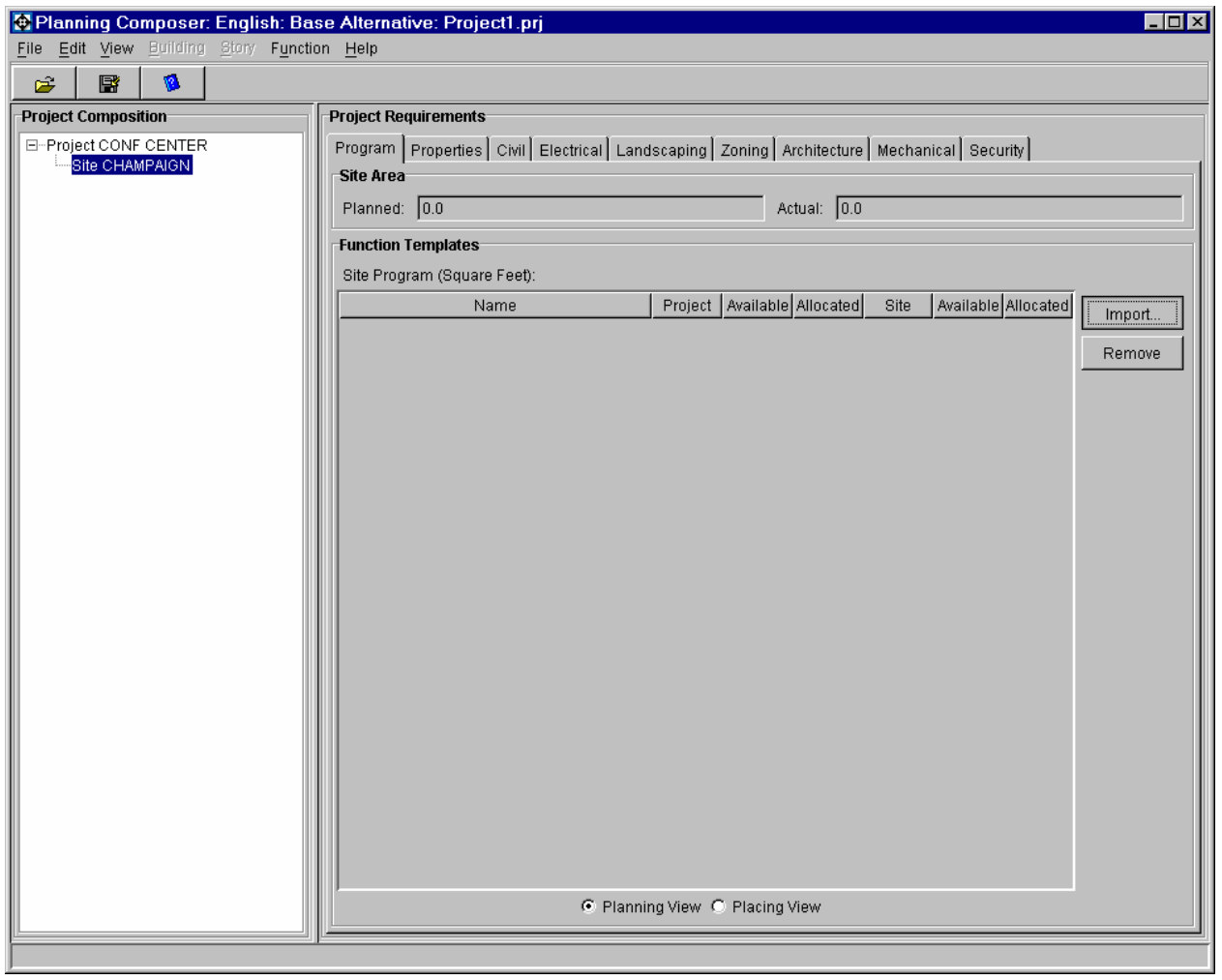

Figure 18. Import button for adding functions.

Result: The Add Function Template dialog box (Figure 19) appears. 


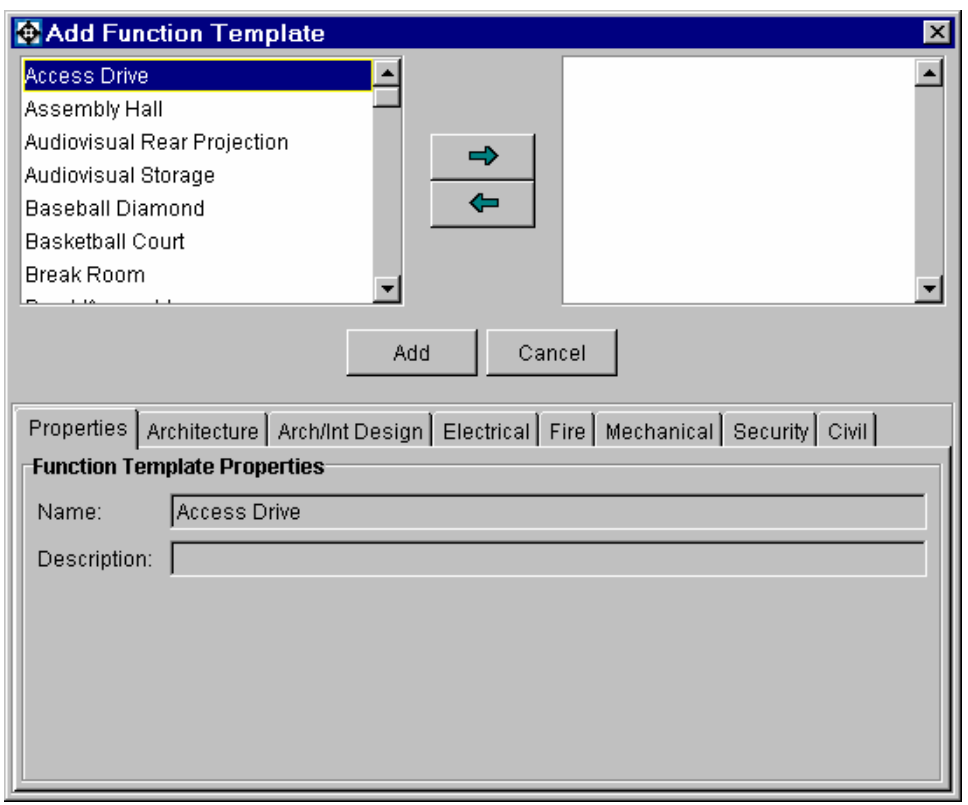

Figure 19. "Add Function Template" dialog box.

The left window displays the list of function templates that are contained in the facility requirements library associated with the current project. Click on one of the templates to select it and notice that the panel on the bottom of the screen changes. Click on the tabs to display the criteria/requirements that come "preloaded" with this template. The Properties tab displays the basic descriptors for the chosen template. The Discipline tabs (Architecture, Electrical, etc.) contain criteria/requirements specific to that particular discipline for the function highlighted.

Templates are added by using the scroll bars, arrow keys, and/or PgUp/PgDn keys to locate the function template desired. Once your selection has been made in the left panel, click on the $\Rightarrow$ button or simply double-click the function template name in the left panel.

Click the Add button to add all the function templates listed in the right panel of the dialog box.

The Program Grid on the main screen (Figure 20) will be updated to display the function templates, which have been added. This can be done at all levels from the Project, Site, Building or Story. 


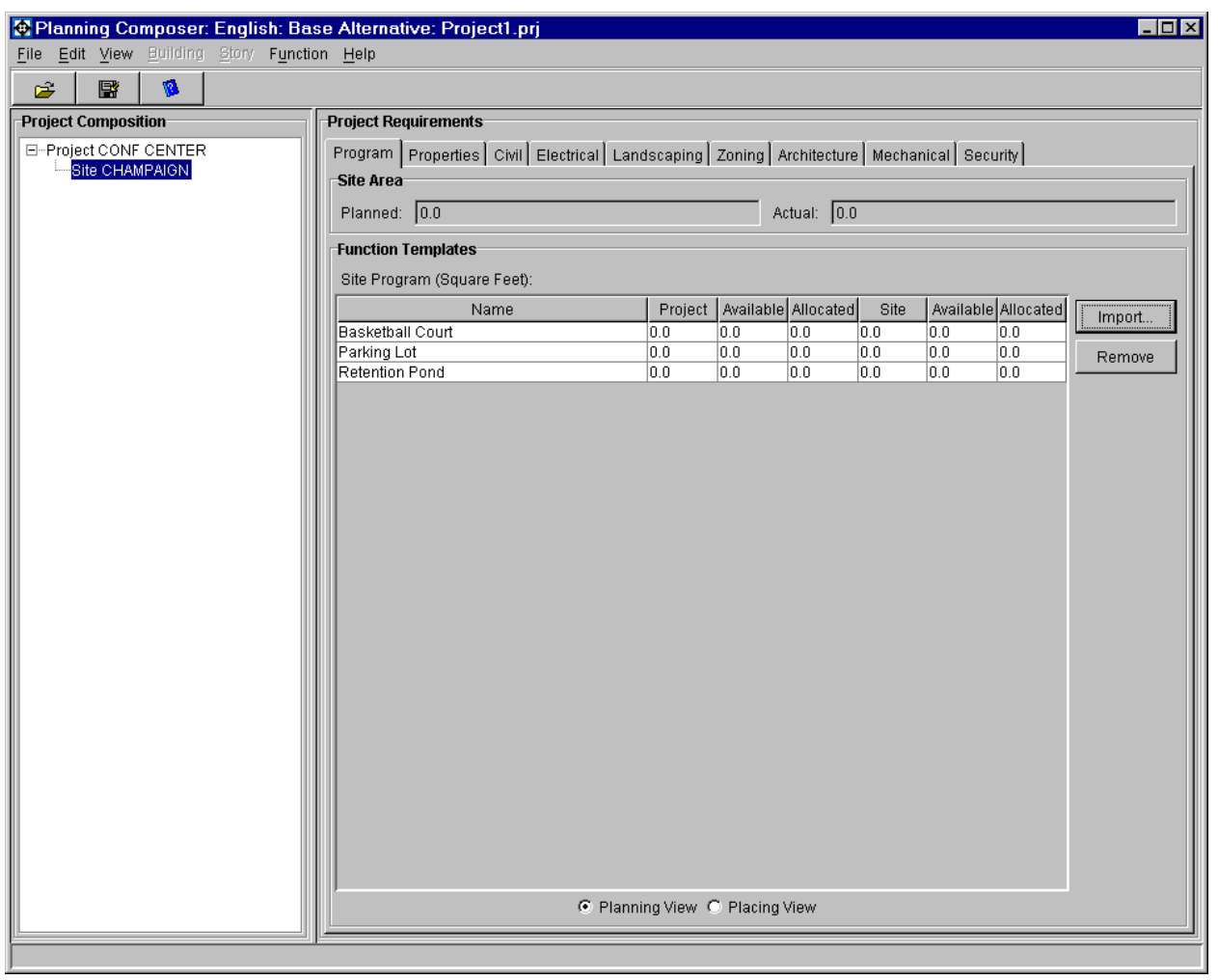

Figure 20. Main program grid with added architectural templates.

\section{Removing a Function Template}

To remove a function template simply highlight the function within the Function Template grid and click the [Remove] button. This will remove the Function from the current level and those below but not from the levels above. For example if you remove a Function Template from the Building Level, it will also be removed on any stories it was on below, but will not be removed from the overall Project level.

\section{Project Requirements Panel}

\section{Working in the Program Grid}

Programming information may be added at any level of the project.

At the Project level (highlight the Project in the Project Composition Tree), you will notice three blank columns followed by a Project column, Available column, and an Allocated column in the Project Program grid (Figure 21). 


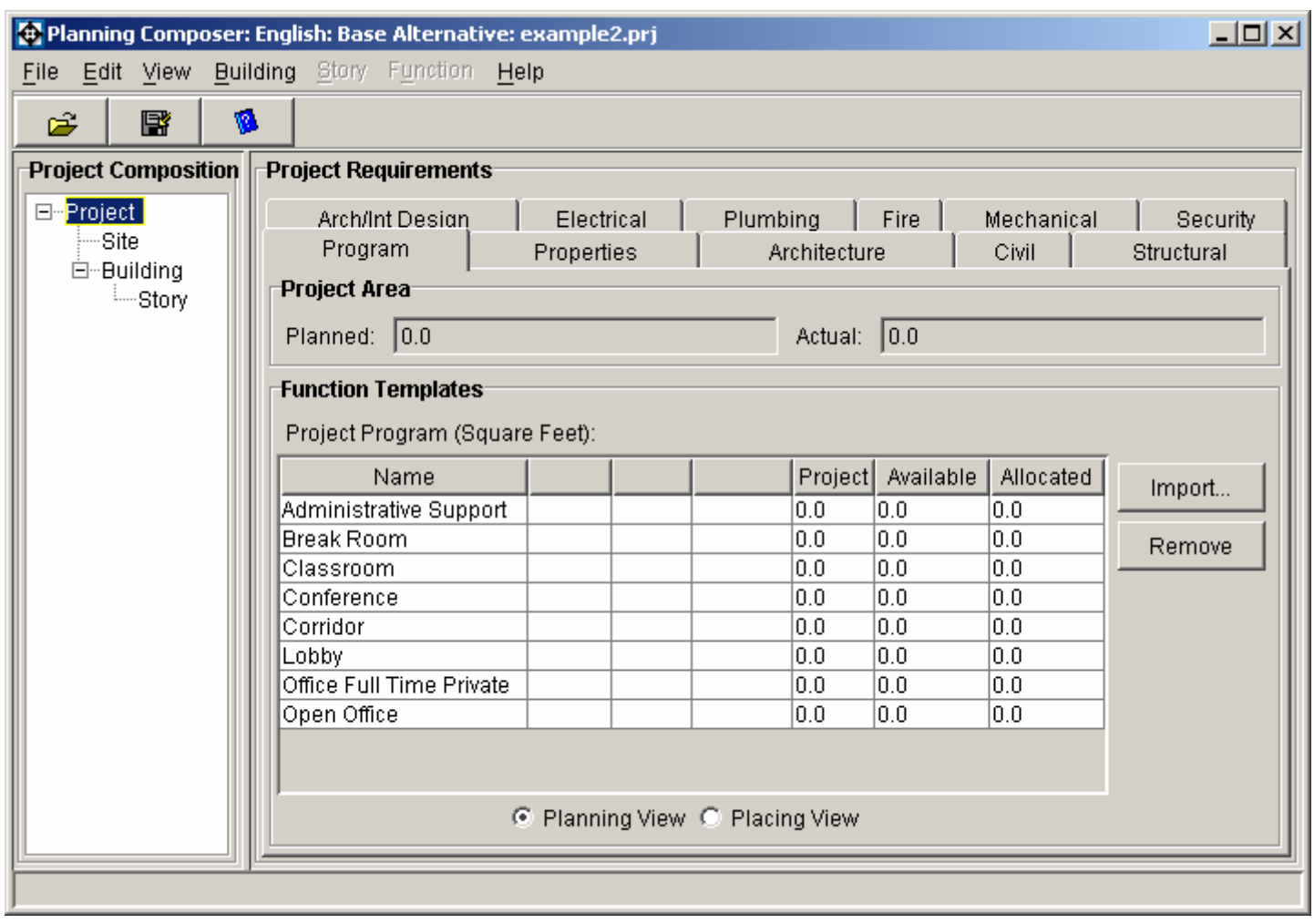

Figure 21. Example blank project program grid

Note: Below the program grid you will notice two radio buttons, one for Planning View and one for Placing View. Placing View is used once actual spaces have been placed. This is used within Layout Composer.

To assign a planned square footage for a function, simply double-click in the Project column in the row of the function that you wish to add a planned area. Next backspace to clear the field, and then type in a value. (If you need to widen a column to see the entire column entry or label, then position your mouse cursor over the vertical bar between columns until the arrow appears. Hold down the left mouse button and slide the bar to the desired width.) After typing in each value, hit the $<$ ENTER $>$ key. Notice that the Planned field in the Project Area portion of the screen reflects the total area that has been planned so far in all of the functional areas (Figure 22).

(The Actual Area will remain at 0 (zero) until you place space objects. Placing space objects will be performed in Layout Composer.)

\begin{tabular}{|c|c|}
\hline Project Area- & \\
\hline Planned: 65150.0 & Actual: 0.0 \\
\hline
\end{tabular}

Figure 22. Project area showing total planned area and total actual area. 
The process is similar for assigning planned area to Site, Buildings, and Stories. One item to note is that the column identifiers will change as you select different levels in the Project Composition Tree. For example, highlight the Building level. Notice that the right three columns (Building, Available \& Allocated) refer to the space usage for the building level, while the left three columns (Project, Available \& Allocated) refer to the space usage for the project level (Figure 23).

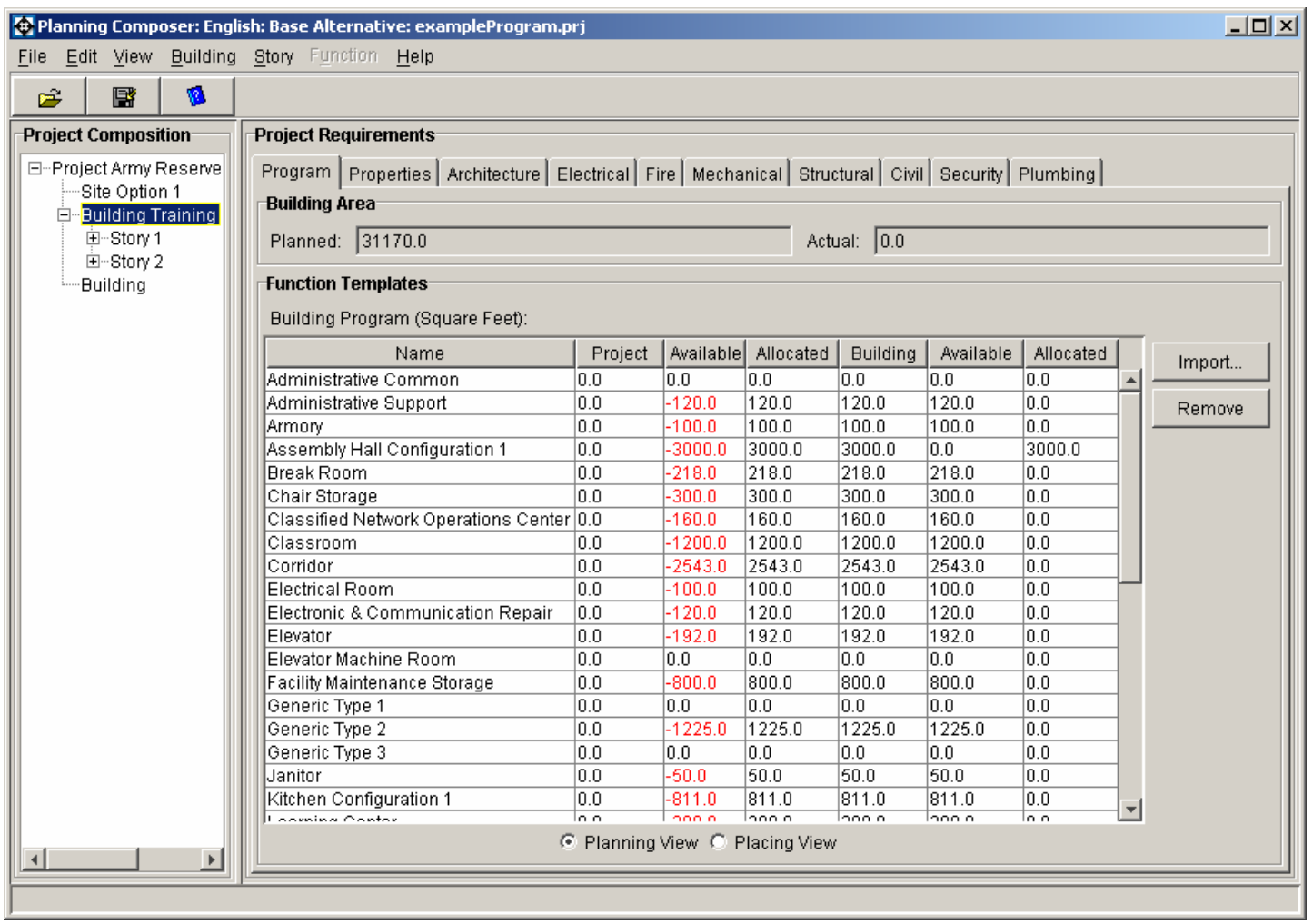

Figure 23. Example program grid for the building level

In the figure above, notice that the values in the Available column appear in red. This reminds us that we are currently underplanned at the Project level. To resolve this, double-click in the Project column of the grid, backspace to clear the field and enter a value. Hit the $<$ ENTER $>$ key or click in a different cell and the Available changes.

To assign planned areas to specific Function Instances, the Area Desired dialog box provides the user a great deal of flexibility.

Select a Function on a Story.

Result: The Function Program grid (Figure 24) appears. 


Function Program (Square Feet):
\begin{tabular}{|c|c|c|c|c|c|c||}
\hline Name & Story & Available & Allocated & Function & Available & Actual \\
\hline Office Shared & 1500.0 & 1500.0 & 0.0 & 0.0 & 0.0 & 0.0 \\
\hline
\end{tabular}

Figure 24. Function program grid.

Click the mouse over the " 0.0 " in the Function column in the grid.

Result: The Area Desired dialog box (Figure 25) opens.

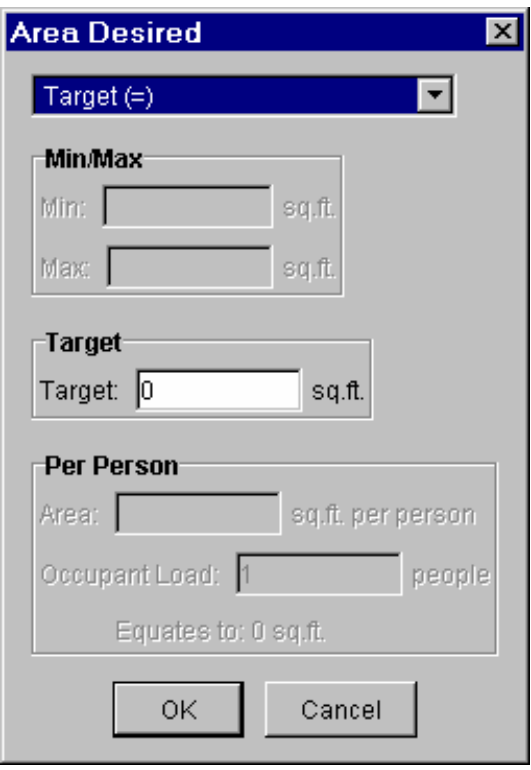

Figure 25. Area desired dialog box.

Click on the arrow in the Target (=) dropdown list box and observe the choices for entering planned area (Figure 26).

\begin{tabular}{|l|}
\hline As Needed \\
Target $(=)$ \\
\hline At Least $(=)$ ) \\
No More Than $(\kappa=)$ \\
Within (min $>=x<=$ max) \\
AreaiPerson $\left(x^{*}\right.$ occupancy) \\
\hline
\end{tabular}

Figure 26. Choices for added planned area at the function level.

Depending on which method you choose for entering values, the dialog box will change to reflect the information required to execute that method. An example of "Area Desired" is show in Figure 27. 


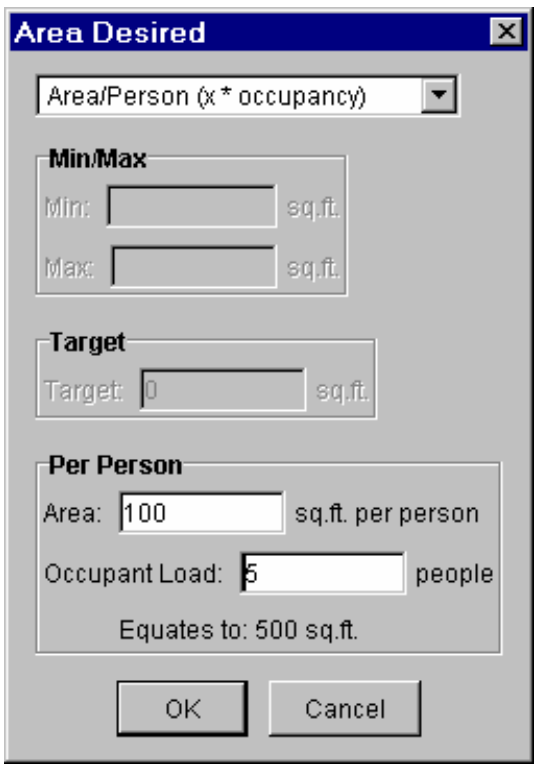

Figure 27. "Area desired" dialog box - "Occupancy per person" option.

\section{Assigning and Modifying Properties}

Click the Properties tab in the Requirements panel. In this panel you can enter information specific to the Object that is highlighted in the Project Composition Tree. For example, if the Project level is highlighted, you may enter values for Project Number, Fiscal Year, Prepared Date, and Prepared By. The Unit field is already populated based on the library that you had previously chosen. Hit the $<$ ENTER $>$ key to update the Project Composition tree.

In the Project Composition tree in the left portion of the screen, click the Site object. (Bear in mind that the right panel of the screen, Requirements, is directly linked to the current (or selected) object in the Project Composition tree or left panel of the screen. If Site is chosen, then the Requirements panel displays information specific to the site (Figure 28). If the Project is chosen, then the Requirements panel displays information that applies to the entire project.) 


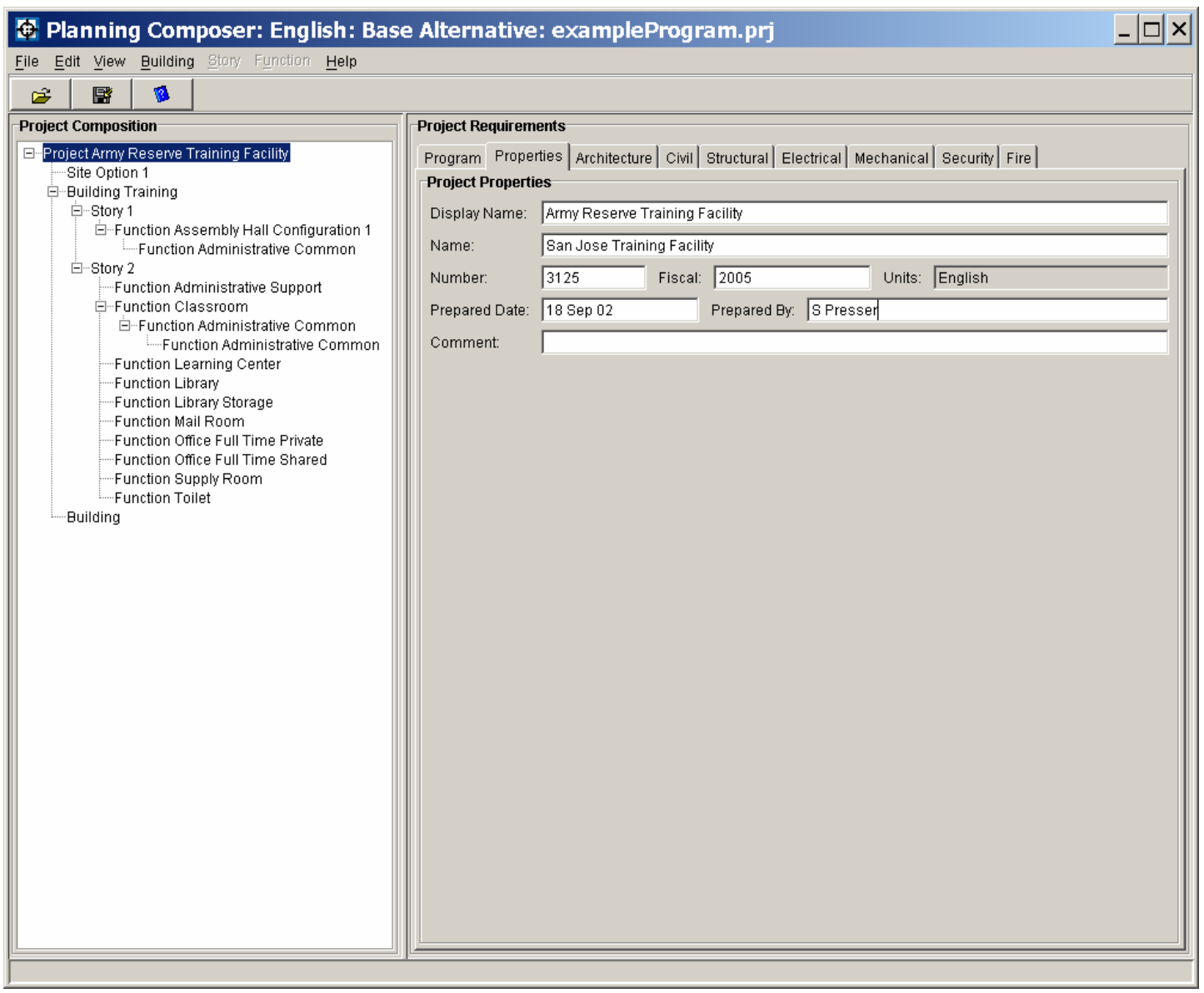

Figure 28. Properties panel.

\section{Working in the Criteria/Requirements Panels}

It is worth noting some special properties of the criteria grid. These properties are true for criteria that the user adds as well as for criteria that come from a library. The criteria grid displays the Category name in red. Values that appear in black are editable. Generally speaking for criteria that comes from the startup library, the Value column and Comment column are editable, while the UOM and Source columns are not. A noneditable field appears in gray on the grid. The Comment field provides a place for the user to add any additional information about the requirement. It is especially useful for annotating the reason when a user decides to override the default value from a library with a project-specific value.

\section{Modifying Criteria}

In the Project Requirements panel, you will notice that there are additional tabs other than Program and Properties. These tabs are used to store crite- 
ria/requirements in any of these different disciplines or categories. Depending on the library that you loaded at project creation, you may have inherited some specific criteria/requirements. You may click the discipline tabs to browse this data if it exists. These may change depending on which level of the Project Composition Tree is selected. More information on the creation of these can be found in ERDC/CERL SR-04-29, Requirements Composer: User's Manual (Construction Engineering Research Laboratory [CERL], October 2004).

To modify criteria, simply browse the preloaded criteria/requirements (Figure 29) and make any necessary changes by either entering a new value or making another selection.

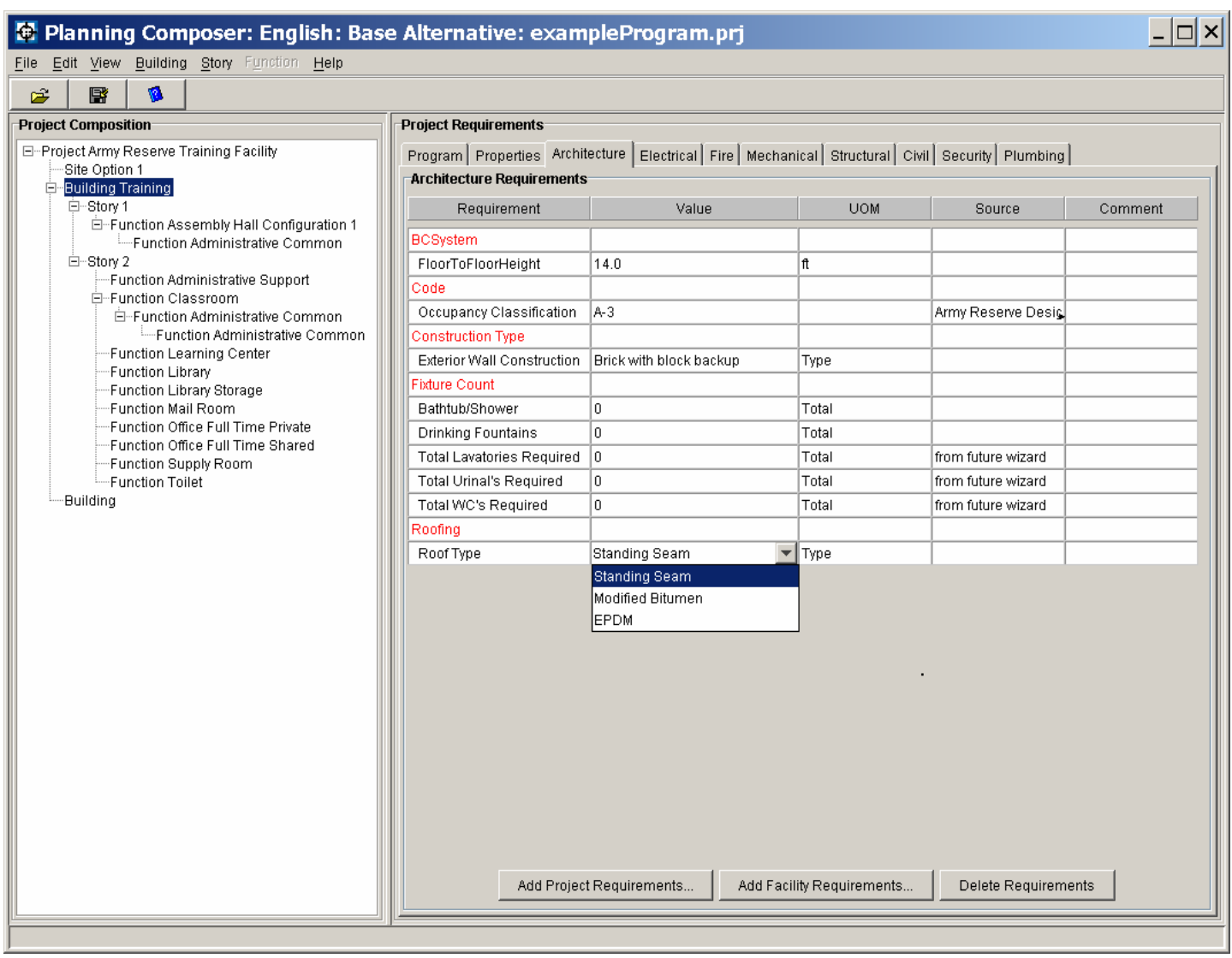

Figure 29. Example of modifying criteria/requirements.

\section{Adding Project Specific Requirements}

It is possible to add criteria/requirements after a project has been created.

Click the Add Project Requirements...

Result: The Add Project Requirements dialog box (Figure 30) opens. 


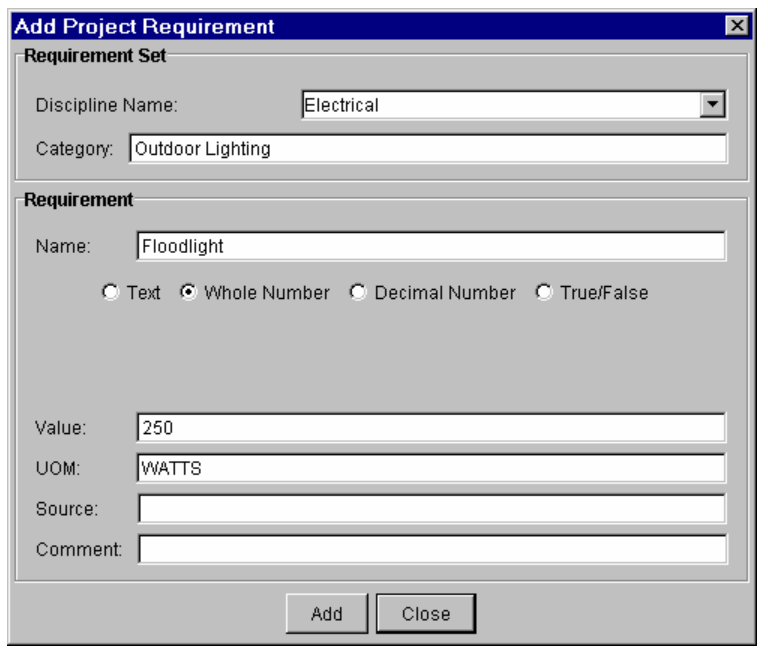

Figure 30. Add Project Requirements Dialog Box.

Choose the discipline tab from the pulldown menu for Discipline Name on which you wish the new requirement to appear (or enter a new name). Decide on a name for this Category. Enter a descriptive Name for the Requirement. Next select the data type radio button. The data type choices include: (1) Text for textual data such as "Incandescent," (2) Decimal for numerical values that will include decimal places such as "0.00056," (3) Whole Number for numerical values without decimal places such as "100" or "-50," and (4) True/False where the only allowed values are either "True" or "False." Enter the criteria Value and enter the UOM (unit of measure) in which the value is recorded. The Source field can be used to designate the source or regulation that has initiated this requirement. The Comment field provides a place to document any additional information about the requirement.

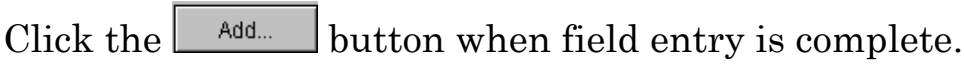

\section{Deleting Criteria}

To delete unneeded criteria/requirements, simply highlight the criteria in the criteria grid and click the [Delete Requirements] button at the bottom of the tab.

\section{Additional Functionality}

\section{Creating Alternatives}

Planning Composer allows the user to store multiple alternate plans or options all within the same project. These options are called Alternatives. Each new 
alternative is based on the Base plan. The Base Alternative is the name given to the initial alternative at project startup/creation. With this feature, you can let the current plan be the base alternative and then branch off into a couple of different directions from there.

From the File menu, choose Create Alternative ...

Result: The Create Alternative dialog box (Figure 31) opens.

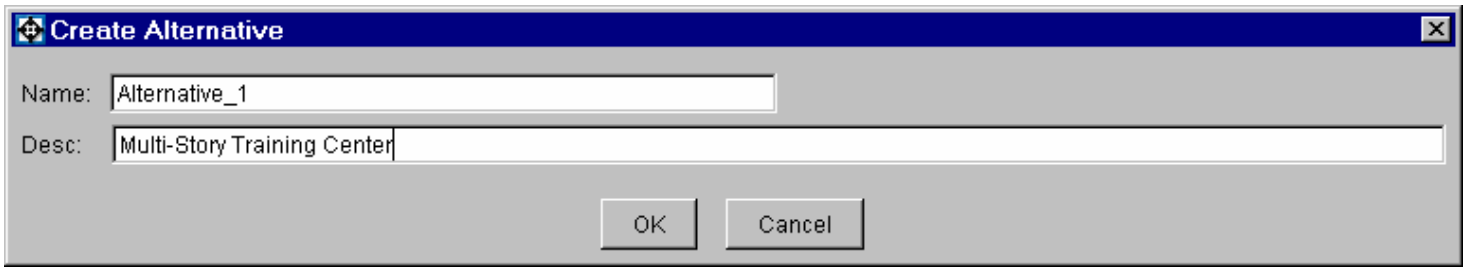

Figure 31. Create alternative dialog box.

The alternative is given a default Name of Alternative 1 , but you may change it if you wish by typing in the name of your choice. In the Desc field, add a description that will distinguish this plan from any other alternatives. Click the ok button to continue.

Result: A confirmation box (Figure 32) informs us the alternative was created.

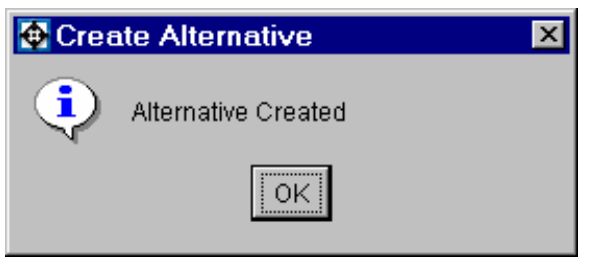

Figure 32. Create alternative dialog.

Next, choose Open Alternative from the File menu.

Result: The Open Alternative dialog box (Figure 33) opens.

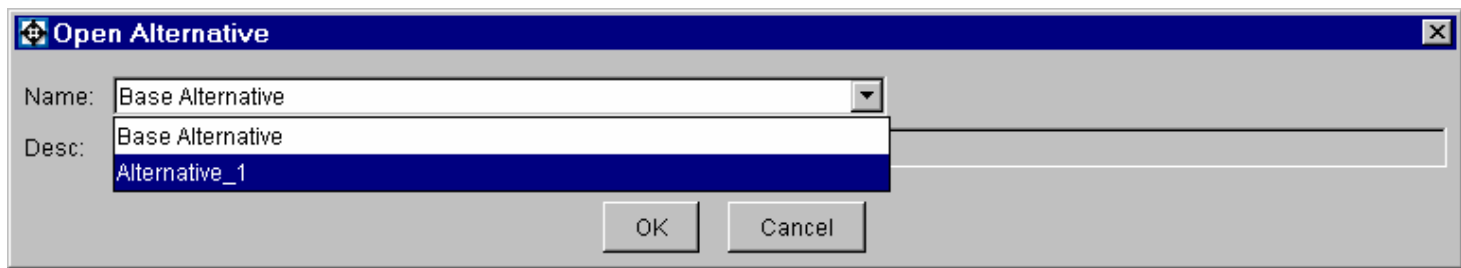

Figure 33. Open alternative dialog box. 
Click the arrow on the pulldown menu in the Name field. Notice that the choices are Alternative_1 and the Base Project. Choose the alternative you want with to work with and then click the $\mathrm{OK}_{\text {button. }}$

\section{Importing and Exporting}

\section{Import Model from Facility Composer XML}

See section Importing a Project of this document.

\section{Export Model to Facility Composer XML}

If you have completed the planning process in Planning Composer and wanted to begin laying out the proposed project in Layout Composer, you will need to export the project to a special XML file. This file can then be read into Layout Composer.

From the File menu, choose Export, and then Export Model to Facility Composer XML...

Result: Export to Facility Composer XML Model dialog (Figure 34) displays

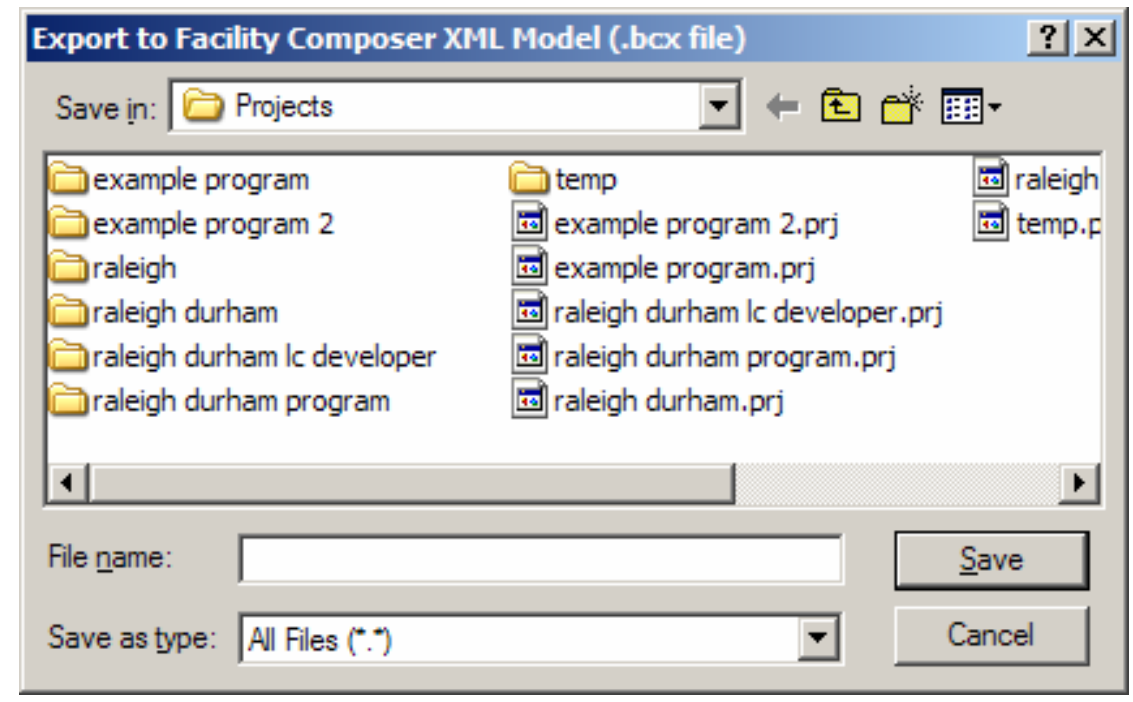

Figure 34. Export model dialog.

Browse to the location where you would like to save the file. Enter an appropriate file name and select the Save button. 


\section{Export Model to IFC-XML 2.X}

Facility Composer has been designed to enable the sharing of project information via the developing object model standard called the Industry Foundation Class. This allows the user to import the project information into other software packages such as PACES cost estimating tool; MicroStation; etc. for further work or analysis. The current working standard is IFC 2.x. It is import for the user to make sure that the software package they would like to use after Planning Composer supports IFC 2.x and that it supports the ifcXML format.

From the File menu, choose Export, and then Export Model to IFC-XML 2.X...

Result: Export to Facility Composer XML Model dialog (Figure 35) displays.

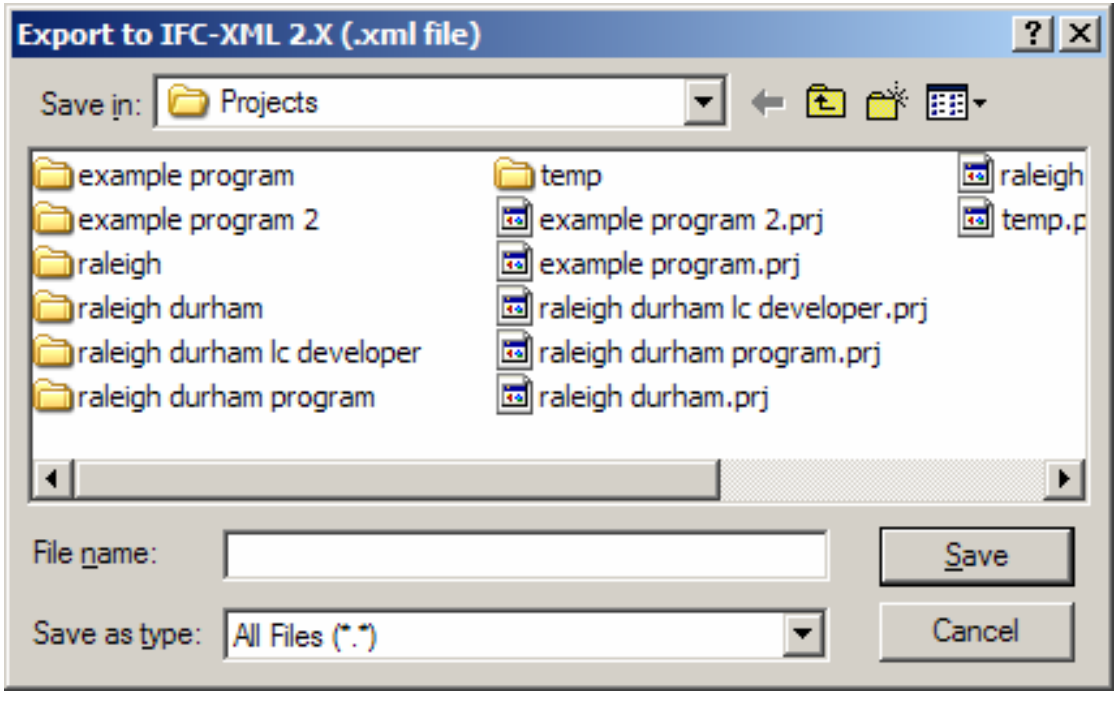

Figure 35. Export to IFC XML 2.X dialog box.

It is very import to remember that depending on the size of the project, this process could take some time so please be patient.

\section{Reports}

There are three standard reports which can be generated at this time. They are a Programmed Area Report, a Function Usage Report, and a Full Project Listing Report 


\section{Programmed Area Report}

From the File menu, choose Report, and then Programmed Area Report...

Result: Programmed Area Report Dialog box (Figure 36) appears.

\begin{tabular}{|c|c|c|c|c|c|}
\hline \multicolumn{6}{|c|}{ Print Preview } \\
\hline First & Previous & Next & Print & Close & \\
\hline & \multicolumn{5}{|c|}{ Facility Composer Project Definition Report } \\
\hline & \multicolumn{5}{|c|}{ 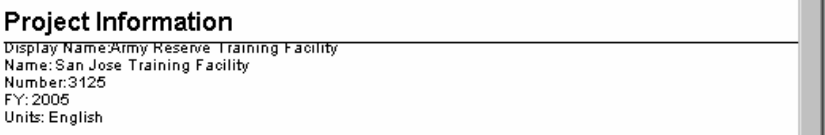 } \\
\hline & \multicolumn{5}{|c|}{ Program Information } \\
\hline & \multicolumn{5}{|c|}{ Function Templates } \\
\hline & \multicolumn{2}{|c|}{ Name } & Planned & Actual & \\
\hline & \multirow{2}{*}{\multicolumn{2}{|c|}{\begin{tabular}{|l|} 
Classroom \\
Generic Type 2 \\
\end{tabular}}} & 1200.0 & 0.0 & \\
\hline & & & 1225.0 & 0.0 & \\
\hline & \multirow{2}{*}{\multicolumn{2}{|c|}{\begin{tabular}{|l} 
Locker Room \\
Office Full Time Private
\end{tabular}}} & 1800.0 & 0.0 & \\
\hline & & ffice Full Time Private & 1280.0 & 0.0 & \\
\hline & \multicolumn{2}{|c|}{$\begin{array}{l}\text { Urit/Individual Storage } 16 \mathrm{x} \\
32\end{array}$} & 0.0 & 0.0 & \\
\hline & \multicolumn{2}{|c|}{$\begin{array}{l}\text { Unit/Individual Storage } 32 \mathrm{x} \\
32\end{array}$} & 0.0 & 0.0 & \\
\hline & \multicolumn{2}{|c|}{ Vending Alcove } & 48.0 & 0.0 & \\
\hline & \multicolumn{2}{|c|}{ Supply Room } & 240.0 & 0.0 & \\
\hline & \multicolumn{2}{|c|}{\begin{tabular}{|l} 
Administrative Support \\
Chir St
\end{tabular}} & \multirow{2}{*}{320.0} & 0.0 & \\
\hline & \multirow{2}{*}{\multicolumn{2}{|c|}{\begin{tabular}{|l|} 
Chair Storage \\
Comidor \\
\end{tabular}}} & & 0.0 & \\
\hline & & & 2543.0 & 0.0 & \\
\hline & \multicolumn{2}{|c|}{ Generic Type 3} & 0.0 & 0.0 & \\
\hline & \multicolumn{2}{|c|}{ Physical Fitness } & 1600.0 & 0.0 & \\
\hline & \multicolumn{2}{|c|}{\begin{tabular}{|l|l} 
Vault Configuration 4 \\
\end{tabular}} & 400.0 & 0.0 & \\
\hline & \multicolumn{2}{|c|}{\begin{tabular}{|l|} 
Electronic \& \\
Communication Repair \\
\end{tabular}} & 120.0 & 0.0 & \\
\hline & Facili & Maintenance & 800.0 & 0.0 & $\nabla$ \\
\hline 1) & & & & & 5 \\
\hline 1 of 6 . & & & & & \\
\hline
\end{tabular}

Figure 36. Programmed area report.

Next Click the [Print] button at the top of the dialog and select a location to save the report.

Note: Make sure when you name the file to save as that you also enter the extension *.pdf. You will need a copy of Adobe Acrobat Reader to view this document.

\section{Function Usage Report}

This particular report simply lists what function templates have been added to the project, their associated planned areas and at what level of the project (i.e., Project, Site, Building, Story) is associated with the template. 
From the File menu, choose Report, and then Function Usage.xls...

Result: Report Output dialog box (Figure 37) appears.

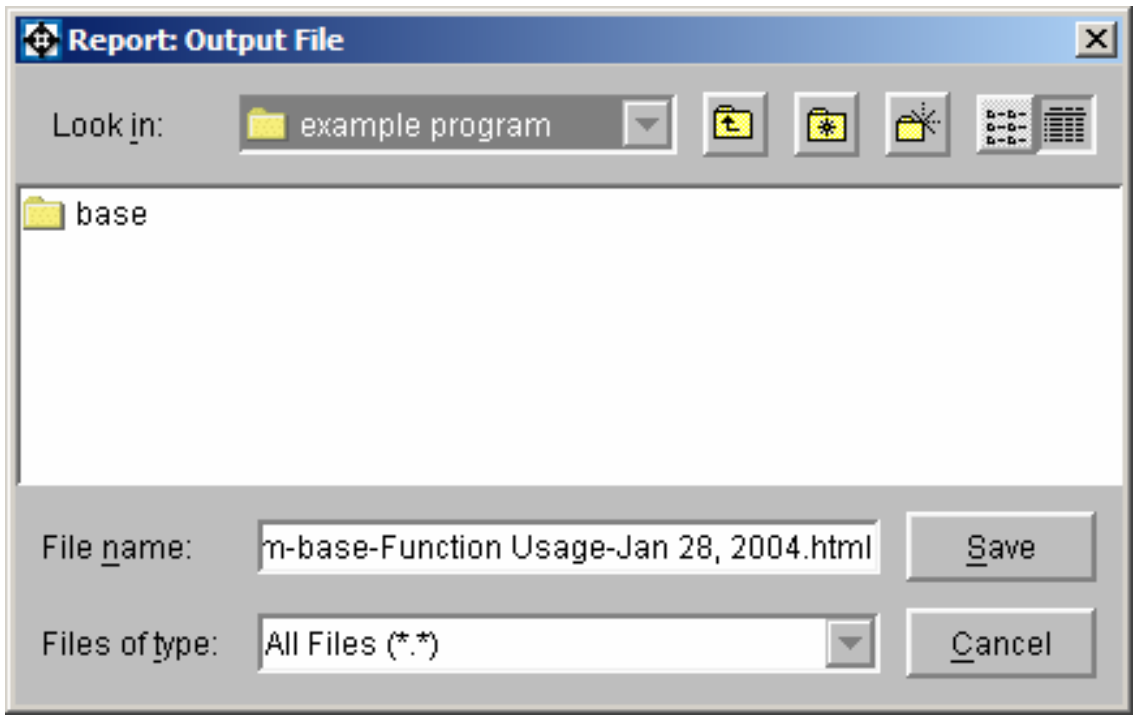

Figure 37. Report output dialog.

Select the file name and location where you would like to save the report file. The default setting is to save the file in the current project directory. An example of the standard file naming convention is:

example program-base-Function Usage-Jan 28, 2004.html

The file is saved in an HTML format so it can be viewed using your standard web browser.

\section{Full Project Listing Report}

The full project listing report is similar to the function usage report, but will display all relevant information regarding the project. It lists the same information as the function usage report, but expands on that by listing what function instances have been added and all criteria/requirements associated with the project as well.

Simply follow the steps in creating a Function Usage Report above except for selecting the Full Project Listing.xsl on the Report menu. 


\section{Conclusion}

This work has composed a User Guide for the Planning Composer software. As one of the primary tools in the Facility Composer application suite, Planning Composer helps users create an architectural program and to set values for project specific criteria. The most important concept of Facility Composer is that customer-specific and computable criteria are associated with a growing facility model that continues throughout the life cycle of the facility. Facility Composer's ability to maintain a linkage between criteria and project elements (site, building, story, etc.) provides many benefits:

- It helps in defining criteria and can help in recording their rationale.

- It helps ensure that critical criteria are followed, and that desired characteristics are recorded and addressed.

- It helps organize criteria and makes them available at their point of use.

- It simplifies creation, maintenance, and distribution of new criteria. For example, as requirements that better implement sustainable design principles are developed, these are added to an organization's standard library for use in subsequent projects. These libraries are typically organized around facility type, but are not required to be. 


\section{Glossary}

\begin{tabular}{|c|c|}
\hline Term & Definition \\
\hline $\begin{array}{l}\text { Actual Area } \\
\text { (Placing View) }\end{array}$ & $\begin{array}{l}\text { (Compare to Planned Area) } \\
\text { The area of the selected object as determined by Facility Composer; it calculates this } \\
\text { value by totaling the areas of all spaces placed at this object level. }\end{array}$ \\
\hline $\begin{array}{l}\text { Allocated Area } \\
\text { (Planning View) }\end{array}$ & $\begin{array}{l}\text { The total area that has been allocated (assigned) to a function for a particular level of } \\
\text { project hierarchy. For example, the total area allocated to a particular function might } \\
\text { be different for the story level, building level, and project level. }\end{array}$ \\
\hline Assigned Function & $\begin{array}{l}\text { (See Function) } \\
\text { A function that was explicitly added to a program by the user. }\end{array}$ \\
\hline Attribute & $\begin{array}{l}\text { (Compare to Requirement) } \\
\text { Physical characteristics of an object; for example, the name, height, and elevation of a } \\
\text { story. }\end{array}$ \\
\hline Building & $\begin{array}{l}\text { An object in the Project Composition hierarchy. A building object contains information } \\
\text { related to a single freestanding physical structure and can be further broken down by } \\
\text { stories, functions and spaces. }\end{array}$ \\
\hline Function & $\begin{array}{l}\text { A function can be related to other functions through three different means: } \\
\text { - A specialization relationship can exist where one function is the parent function and } \\
\text { the other function is the child function, for example, the relationship between an of- } \\
\text { fice and private office. A private office is a specialization of the office. The office is } \\
\text { the parent function and the private office is the child function. } \\
\text { - A spatial containment relationship can exist where one function physically contains } \\
\text { another function, for example, the relationship between a lobby and the reception } \\
\text { area. The lobby is the super-function and the reception area is the sub-function. } \\
\text { - The final relationship is that of assigned and unassigned functions. This type of } \\
\text { relationship supports the 'roll-up' capability through item programs. }\end{array}$ \\
\hline Function Template & $\begin{array}{l}\text { A Function definition from a library. Templates are the parents of specific function in- } \\
\text { stance objects added to project elements (site, story, etc.) }\end{array}$ \\
\hline Function Instance & $\begin{array}{l}\text { Function objects created from function templates and assigned to project elements. } \\
\text { All function instances created from the same function template aggregate their areas } \\
\text { for project planning purposes. }\end{array}$ \\
\hline Object & $\begin{array}{l}\text { An element (or node) in the Project Composition structure. Since there is a hierarchi- } \\
\text { cal relationship between all objects in this structure the structure is often referred to as } \\
\text { a "tree." The PROJECT object occupies the highest level of the hierarchy. From } \\
\text { highest level to lowest level, the other objects include: BUILDING (and SITE), STORY, } \\
\text { FUNCTION, and SPACE. }\end{array}$ \\
\hline Planned Area & $\begin{array}{l}\text { The total area for the selected project element or for a specific function at a particular } \\
\text { level in the project hierarchy (project, building, etc.) as determined and entered by the } \\
\text { user. This value expresses the estimated and desired area for this object. In later } \\
\text { stages of project development when spaces have been placed, the Actual Area value } \\
\text { will be compared to the Planned Area value to determine how closely the project lay- } \\
\text { out is meeting the initial plan. }\end{array}$ \\
\hline
\end{tabular}




\begin{tabular}{|l|l|}
\hline Term & Definition \\
\hline Program & $\begin{array}{l}\text { A group of function templates added to a Project, Site, Building or Story project ele- } \\
\text { ment for planning purposes. Planned areas are typically assigned during program } \\
\text { development. }\end{array}$ \\
\hline Project & $\begin{array}{l}\text { A set of information pertaining to a building/construction project. In Facility Composer, } \\
\text { the project object occupies the highest level of the Project Composition tree. All infor- } \\
\text { mation for a Facility Composer project is stored in a PRJ file and directory that the } \\
\text { user names on project creation. In Facility Composer, only one project may be } \\
\text { opened at a time. }\end{array}$ \\
\hline
\end{tabular}




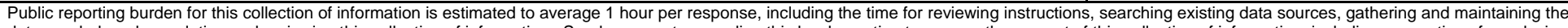

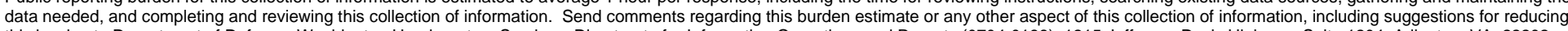

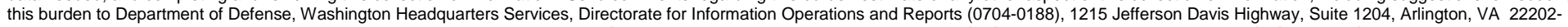

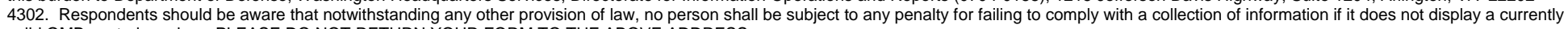
valid OMB control number. PLEASE DO NOT RETURN YOUR FORM TO THE ABOVE ADDRESS.
1. REPORT DATE (DD-MM-YYYY)
$11-2004$

\section{REPORT TYPE}
Final

4. TITLE AND SUBTITLE

Planning Composer User's Guide:

Through Beta Version 0.22

3. DATES COVERED (From - To)

5a. CONTRACT NUMBER

5b. GRANT NUMBER

5c. PROGRAM ELEMENT NUMBER

6. AUTHOR(S)

Susan D. Nachtigall and Beth A. Brucker

\section{5d. PROJECT NUMBER}

5e. TASK NUMBER

5f. WORK UNIT NUMBER

LK6K75-N

\section{PERFORMING ORGANIZATION NAME(S) AND ADDRESS(ES)}

U.S. Army Engineer Research and Development Center (ERDC)

Construction Engineering Research Laboratory (CERL)

8. PERFORMING ORGANIZATION REPORT NUMBER

ERDC/CERL SR-04-31

PO Box 9005

Champaign, IL 61826-9005

\section{SPONSORING I MONITORING AGENCY NAME(S) AND ADDRESS(ES)}

Headquarters,U.S. Army Corps of Engineers (HQUSACE)

\section{SPONSOR/MONITOR'S ACRONYM(S)}

CEERD-CV-ZT

441 G Street, NW.

Washington, DC 20314-1000

11. SPONSOR/MONITOR'S REPORT NUMBER(S)

\section{DISTRIBUTION I AVAILABILITY STATEMENT}

Approved for public release; distribution is unlimited.

\section{SUPPLEMENTARY NOTES}

Copies are available from the National Technical Information Service, 5285 Port Royal Road, Springfield, VA 22161.

\section{ABSTRACT}

Over the past several years, the Architectural Engineering and Construction (AEC) industry has been making a substantial effort to create an standard facility modeling format known as the Industry Foundation Class (IFC), which has now made it possible to capture criteria and requirements during planning and design, and then to reuse this data during the life cycle of the facility. This research effort is part of the "Fort Future" program, which is developing a capability to model, simulate, assess, and optimize installation capabilities to support the Objective Force. The Facility Acquisition component of Fort Future, Facility Composer, will shorten the time required to acquire facilities while ensuring that Objective Force and Future Combat Systems (FCS) criteria and requirements are met. Facility Composer tools support capturing and tracking of facility criteria and requirements, planning and design charrettes, and associated planning and design analyses. Planning Composer is one of the primary tools in the Facility Composer application suite, which helps users create an architectural program and to set values for project specific criteria. This work contains a User Guide for the Planning Composer software.

\section{SUBJECT TERMS}

fort future

facility planning

16. SECURITY CLASSIFICATION OF:

\section{a. REPORT}

Unclassified

\section{b. ABSTRACT \\ Unclassified}

facility composer

planning c. THIS PAGE Unclassified 17. LIMITATION
OF ABSTRACT

SAR facility design

software

18. NUMBER OF PAGES

48 19a. NAME OF RESPONSIBLE PERSON
Susan D. Nachtigall
$\begin{aligned} & \text { 19b. TELEPHONE NUMBER (in- } \\ & \text { clude area code) } \\ & 217-373-4579\end{aligned}$ 